\title{
LA SOBERANÍA NACIONAL EN LA CONSTITUCIÓN DE CÁDIZ
}

ANTONIO TORRES DEL MORAL 


\section{SUMARIO}

\section{INTRODUCCIÓN: LA LARGA MARCHA DE LA SOBERANÍA DESDE}

EL PLURALISMO FEUDAL HASTA EL PENSAMIENTO ILUSTRADO: 1.1. La soberanía de origen divino. 1.2. Hacia la terrenalización de la soberanía. 2. SOBERANÍA NACIONAL VERSUS SOBERANÍA POPULAR: 2.1. La tópica teoría diferenciadora. 2.2. Su insuficiencia: 2.2.1. Aproximación al problema. 2.2.2. Textos doctrinales y jurídicos: 2.2.2.1. Textos franceses. 2.2.2.2. Textos americanos. 3. LA CIUDADANÍA COMO CONCEPTO CLAVE: 3.1. Textos doctrinales y jurídicos: 3.1.1. Textos franceses. 3.1.2. Textos americanos. 4. LA SOBERANÍA NACIONAL/POPULAR EN LA CONSTITUCIÓN ESPAÑOLA DE 1812: 4.1. Previa mirada al constitucionalismo histórico español. 4.2. En especial, la Constitución de 1812: 4.2.1. La soberanía. 4.2.2. La nación como Estado. 5. LA CIUDADANÍA EN CÁDIZ: 5.1. Derecho de ciudadanía. 5.2. Españoles y ciudadanos. 5.3. La condición de ciudadano, jurídicamente abierta. 5.4. Alguna comparación para evitar anacronismos. 5.5. Conclusión: el controvertido sufragio «gaditano». 6. PODER CONSTITUYENTE POPULAR: 6.1. Soberanía y poder constituyente. 6.2. Textos iniciales del constitucionalismo. 6.3. Constitución gaditana: 6.3.1. Titularidad del poder constituyente y poder de reforma constitucional. 6.3.2. Constitución y ley. 7. CONCLUSIÓN Y REMISIÓN: UNA INCIPIENTE DEMOCRACIA REPRESENTATIVA. 


\title{
LA SOBERANÍA NACIONAL EN LA CONSTITUCIÓN DE CÁDIZ ${ }^{1}$
}

POR

\author{
ANTONIO TORRES DEL MORAL \\ Catedrático de Derecho Constitucional \\ UNED
}

\section{INTRODUCCIÓN: LA LARGA MARCHA DE LA SOBERANÍA DESDE EL PLURALISMO FEUDAL HASTA EL PENSAMIENTO ILUSTRADO}

\subsection{La soberanía de origen divino}

No es propósito de este epígrafe hacer un estudio de la soberanía, estudio tantas veces hecho aunque sea susceptible de no pocos matices, como tampoco entrar minuciosamente en los caracteres que diversos pensadores le han atribuido ni en las polémicas multiseculares sobre la misma. Sólo nos interesa una de esas versiones, para cuyo análisis trazaremos en este epígrafe únicamente unos apuntes sobre su origen y evolución como reza su rótulo.

Hace más de medio siglo, Nicolás RAMIRO RICO abría su singular estudio sobre la soberanía con estas palabras: «No hay piropo que no haya regalado a la soberanía; no hay diatriba que no la haya afligido. Ensalzada por unos, abuchea-

${ }^{1}$ Este trabajo ha sido realizado dentro del Proyecto de Investigación DER2009/11050 «Prehistoria del Derecho Constitucional», financiado por el Ministerio de Educación y Ciencia, del que el autor es Investigador Principal. 
da por otros, la soberanía, nacida en ocasión dramática, continúa enardeciendo los corazones de todos. Tras Bodino, pocos habrá que con ánimo sereno — sine ira et studio - traten de investigarla». Una de las causas de ello estriba en la mezcla de política y religión que enseñoreó el pensamiento político durante siglos, lo que hizo de la soberanía más objeto de la Teología que de la Teoría Política².

«Nulla potestas nisi a Deo», rezaba la sentencia paulina ${ }^{3}$, que nadie discutía o nadie se atrevía a hacerlo. Y, desde Carlomagno, emperadores y reyes ostentaron su poder «por la gracia de Dios». Por eso, cuando se encontraban en dificultades, buscaban en su legitimación por Roma un título que afianzara su dudosa posición. De este modo, emperadores y príncipes devenían vicarios de Dios, lo que, de un lado, reforzaba su posición, pero, de otro, la mediatizaba a través del Pontificado ${ }^{4}$.

Las dos tensiones estaban entrelazadas puesto que, en tanto no se lograba una cierta independencia respecto de esos poderes «generales» (imperial y pontificio), con pretensiones planetarias o poco menos, difícilmente se podía conseguir la supremacía en el interior. Costó varios siglos conseguir la superación de este equilibrio inestable. Al decir de HINSLEY, hasta entrado el siglo XVI pervivió la creencia de que la Corona se veía obligada a compartir el poder con las autoridades exteriores y que, en el interior, no estaba libre de obligaciones y vínculos 5 .

De otra parte, como dice RAMIRO RICO, a la larga, el triunfo fue de las dinastías territoriales porque supieron aprovechar el dualismo Iglesia-Imperio para transferir constantemente su lealtad de la una al otro y viceversa. «La base misma del antagonismo entre Iglesia e Imperio... dictaba a las dinastías su voluble y versátil conducta»; y, cuando se sintieron suficientemente fuertes, requirieron para sí lo que había sido nota de los dos grandes poderes: la soberanía ${ }^{6}$. De manera que ésta nació como poder superior o supremo en el Estado y poder independiente de ese Estado en el concierto internacional.

El mundo no consistía ya en un universo político dirigido por uno o los dos «señores del orbe», sino en un pluriverso de Estados soberanos que no admitían

2 RAMIRO RICO, N.: «La soberanía», Revista e Estudios Políticos (en adelante RDP), nº 66, Madrid, 1952; posteriormente incluido en el volumen El animal ladino y otros escritos, Alianza, Madrid, 1980, págs. 119 ss., por donde cito.

3 PABLO DE TARSO: Epístola a los Romanos, 13.

${ }^{4}$ RAMIRO RICO, N.: «La soberanía», ob. cit., págs. 120-121 y 125-126.

${ }^{5}$ HINSLEY, F. H.: El concepto de soberanía, edic. cast., Labor, Barcelona, 1972, pág. 96.

${ }^{6}$ RAMIRO RICO, N.: «La soberanía», ob. cit., págs. 126-127. 
injerencias externas en su interior y que participaban en el concierto de las naciones/Estados en pie de igualdad con los demás, al menos, de igualdad formal.

La misma crisis del Estado, sobre la que se especula desde hace un siglo, se intenta identificar como una crisis de su soberanía (y de nuevo vale decirlo a la inversa) en sus dos dimensiones: en el orden externo, por la existencia de instancias internacionales y supranacionales respecto de las cuales los Estados no sólo no adoptan una actitud de rechazo, sino que insta su incorporación a ellas, lo que se traduce en la adaptación de su política a la de dichos entes, al menos en algunos - pero crecientes - aspectos. Y en el interior, por la descentralización política adoptada por muchos Estados, que en ciertos casos llega a la cesión a entes regionales de competencias de dirección política y legislación, e incluso se dotan de una estructura federal.

No obstante lo cual, parece que el «próximo» fin del Estado, pese a la literatura vertida en tal dirección, se aleja cada vez que creemos estar llegando a él.

\subsection{Hacia la terrenalización de la soberanía}

El problema sobre el que versa este trabajo se apoya en el deslinde anterior para ocuparse solamente de la soberanía como supremacía interior, esto es, de la soberanía en el Estado, no en la del Estado en el concierto internacional. Escisión que, como hemos indicado, no se produce ni se puede producir en la realidad, pero que, al deslindar dos dimensiones conceptualmente diferentes del fenómeno, admite su análisis separado. Una vez dentro del terreno libremente escogido y a fin de mejor centrarnos en el análisis jurídico, soslayaremos el ingrediente fáctico en el que históricamente se apoyaron los reyes para imponerse a los demás poderes «concurrentes».

Asentado el principio de que el Estado es soberano y de que en el Estado hay un poder superior a todos, el paso siguiente, a saber, el de determinar cuál es el sujeto titular de ese poder supremo, no admitió discusión en su inicio: justamente quien había creado el Estado con su fuerza y su astucia (he aquí los símbolos maquiavelianos del león y la zorra), o bien quien, con idénticas armas, hubiera sabido desplazarlo, aunque tanto en uno como en otro caso se acudiera a Dios, a través de Roma, para santificar el hecho.

Pero los nuevos aires que se respiraban desde el Renacimiento dificultaban progresivamente el mantenimiento de la doctrina paulina y agustiniana y demandaban algo más. La dedicación del saber político, como quería MAQUIAVELO, al estudio de la Historia y a la observación de la realidad mejor que a la imaginación de repúblicas perfectas; la doctrina de la razón de Estado, difundi- 
da por BOTERO; la teoría bodiniana de la soberanía absoluta ${ }^{7}$; la aportación de la pléyade de juristas y teólogos de las Escuelas de Salamanca; las doctrinas contractualistas, tan similares en la hipótesis metodológica inicial como diferentes, y aun encontradas, en sus desarrollos y puntos de llegada; el iusnaturalismo racionalista, frecuentemente emparentado con el pactismo, y otras tantas corrientes de pensamiento apuntaban ya claramente a un nuevo orden.

En sustitución terrenal de la soberanía se ideó el origen de la comunidad política en un pacto inicial de las personas que vivían asocialmente en un territorio, o bien dos pactos, si se arbitraba que mediante el primero, el pacto social o de asociación, se acordaba la vida en común (pactum unionis), y con el segundo, el pacto propiamente político, la comunidad se sometía al poder instituido (pactum subiectionis); o incluso un tercero, como aduce PÉREZ SERRANO, para concretar la forma de gobernarse ${ }^{8}$. Obviamente, el pacto o los pactos eran meras hipótesis teóricas, aunque no faltaron quienes, apoyados en los conocimientos que se iban teniendo de la vida de los pueblos indígenas americanos, aceptaban que hubieran sucedido en algún lugar en algún momento.

Esta construcción teórica tenía precedentes interesantes que, por no remontarnos a la Antigüedad clásica, podemos cifrar en el ya aludido pluralismo feudal y la practica pactista existente en cada Reino, pero era un pactismo de otra naturaleza. Práctica que había decaído ya con la supremacía indiscutida del Príncipe y la instauración de un régimen absoluto, pero quedó la idea como una «ley vieja» o «ley venerable», que de vez en vez era recuperada, y más bien adulterada, en las escasas convocatorias que los monarcas hicieron de los Parlamentos durante los dos siglos anteriores a la Revolución Francesa. Estas convocatorias se hacían a los meros efectos consultivos del Monarca, el cual gustaba tomar decisiones en Parlamento, en cuyas ocasiones éste venía a ser, dicho con palabras de BODINO, la solemnidad del Príncipe. Pero, aun así, la referida idea pactista no dejó de tener cierta presencia en estas nuevas teorías sobre nuestro objeto por cuanto comportaba el principio del consentimiento de los súbditos ${ }^{9}$, más bien de ciertos súbditos muy señalados.

Diferían los pensadores que acogieron esta doctrina hasta el punto de que para algunos era la antesala de la soberanía nacional (LOCKE), o incluso su más acabada explicación, sea para bien, en el supuesto de un pacto igualitario, sea para mal, que

7 En la edición francesa es definida como «puissance absolue et perpétuelle d'une République»; y en la latina: «summa in cives ac subditos legibusque soluta potestas». Sin embargo, BODINO terminaba admitiendo varios límites: el Derecho divino y el natural, instituciones de Derecho civil como el contrato y la propiedad privada, y las normas fundamentales o leges imperii, que disciplinaban principalmente el régimen sucesorio en la Corona.

8 PÉREZ SERRANO, N.: Tratado de Derecho Político, Civitas, Madrid, 1976, pág. 141.

9 Cfr. HINSLEY, F. H.: El concepto de soberanía, ob. cit., pág. 93. 
es lo que ha sucedido históricamente a la vista del Estado y de la sociedad realmente existentes, basados en un pacto leonino (ROUSSEAU), mientras que para otros (HOBBES) era la justificación de la única forma posible de Estado, el totalitario, sólo que supuestamente ejercido «por representación». Versiones de las que ha sido la lockeana la que ha prevalecido en las democracias liberales de Occidente.

El hecho de haber tardado siglos en abrirse paso en la realidad política (y aun así lo hizo asistida de revoluciones, no todas incruentas) se debió indudablemente a que encerraba en sí una complejidad hasta entonces insospechada:

a) se instituía un poder y su titular para la gobernación del país;

b) que ya no era el supremo porque éste permanecía en la comunidad (la excepción está representada por HOBBES);

c) la cual se reservaba la facultad de deponer o revocar al titular instituido,

d) si éste no cumplía su función, que era la defensa de los derechos de quienes lo habían aupado a su preeminente posición.

\section{SOBERANÍA NACIONAL VERSUS SOBERANÍA POPULAR}

Volvamos al escenario del pacto. Es obvio que los pactantes acuerdan un orden político porque pueden hacerlo, porque tienen poder para adoptar tan crucial decisión. Dicho en otros términos: el poder de fundación de un orden político reside en los miembros de la colectividad. Si llamamos soberanía a ese poder, tenemos otro de los elementos de la ideología constitucionalista: la soberanía nacional. Así lo entendieron algunos pensadores ilustrados y fue también solemnemente proclamado por la Declaración de 1789.

Consiguientemente, no todo consistía en dicho cambio en la titularidad de la soberanía, sino en el nuevo principio de legitimidad política. Esta nueva legitimidad descansaría sobre el principio de soberanía nacional por oposición a la soberanía monárquica sustentadora del régimen anterior a extinguir. Pero, aunque la teoría concerniente a esta cuestión es conocida, no siempre lo es con precisión. Afrontémosla, por tanto, aunque sea con brevedad.

Conforme a la Declaración de Derechos del Hombre y del Ciudadano, que inaugura solemnemente la cultura constitucional del Nuevo Régimen ${ }^{10}$,

10 Declaración solemne, declamatoria, mesiánica y de pretendido alcance universal, a diferencia de los textos ingleses y su Gloriosa Revolución, que sólo se proponían, más modestamente, arreglar las cosas propias, esto es, los derechos de los ingleses y la forma política conducente a ello, y a diferencia igualmente de la entonces reciente Constitución deferal norteamericana. 
¿quien habría de decidir en el origen y, después, respecto del grado de satisfacción de su ejercicio: un grupo de notables aristócratas, los beati possidentes, todos los ciudadanos, todas las personas que viven en la comunidad, incluidos los extranjeros...? Desechemos las alternativas aparentes o anacrónicas y quedémonos con las reales: ¿todos o unos cuantos?

\subsection{La tópica teoría diferenciadora}

Hay quien llama nación a esos «unos cuantos» y pueblo a esos «todos». ¿Razones? Escasas y endebles. Acaso por eso $-\mathrm{y}$ no ironizo, puesto que el asunto ha llegado en ocasiones a alcanzar tintes trágicos- han terminado por desplazar otras razones mejor fundadas.

En efecto, desde hace algún tiempo es usual en tratados, manuales y monografías oponer soberanía nacional y soberanía popular por entender que pueblo y nación son realidades y conceptos diferentes. Según esta teoría, la nación no es el conjunto de habitantes de un país, sino que incluye las generaciones pasadas, presente y futuras, incluye también la cultura, la lengua, la Historia patria, la religión en algunos casos, los sentimientos y, sobre todo, los intereses particulares y colectivos. Entonces, mediante un fácil reduccionismo, y dado que ni las generaciones pasadas ni las futuras se hacían presentes en el debate, a la hora de la verdad efectiva, se terminaba identificando la nación con los intereses económicos más consolidados: la nación es el conjunto de propietarios. Y, en este caso, la soberanía nacional no parecía requerir la universalidad del sufragio, sino sólo el sufragio censitario (restringido a los propietarios, títulos de nobleza, etc.).

Los mantenedores de la diferencia entre pueblo y nación insisten todavía en que la idea de soberanía nacional está en línea con la posición sustentada por MONTESQUIEU y fue acogida por el constitucionalismo liberal de la primera mitad del siglo XIX.

Por su parte, siempre según esta teoría, pueblo equivale al conjunto de habitantes de un país; y, por lo tanto, la idea de soberanía popular, que sería de origen rusoniano, sí exige el sufragio universal y fue sostenida por las democracias emergentes y los movimientos populares del siglo XIX.

Es ésta hoy la posición más extendida, casi unánime, entre nosotros, así como son también son casi unánimes las preferencias por la soberanía popular por el motivo indicado de ser considerada la única propia de la democracia. 


\subsection{Su insuficiencia}

\subsubsection{Aproximación al problema}

Fijémonos bien: esta teoría sustenta dos conceptos diferentes, e incluso enfrentados, de soberanía, la nacional y la popular, le asigna un autor clásico de prestigio universal como referencia, patrón o «jefe de fila», y le adjudica un modelo de sufragio y su respectiva proyección constitucional en la Historia.

Así expuesta, tal teoría tiene la brillantez de lo elemental y de lo simétrico, pero la falsedad de lo superficial y de lo esquemático. Se trata de una teoría más sugestiva que científicamente sólida.

En ciertos autores, incluso muy cualificados, se observa una gran confusión y discrepancias poco justificadas. N. PÉREZ SERRANO, con la elegante prosa que lo caracteriza, acierta plenamente cuando advierte que la confusión entre nación y pueblo hace a veces imposible interpretar con seguridad los textos constitucionales. Tienen en común, dice, su repulsa de la soberanía regia y la designación como titular a los ciudadanos, pero la discrepancia surge sobre si éstos han de ser considerados uti singuli o bien uti universi. Sin embargo, tan ilustre autor no escapa a su mismo diagnóstico cuando pasa a describir estas supuestas dos especies $^{11}$.

\subsubsection{Textos doctrinales y jurídicos}

Los términos pueblo y nación, que tenían un origen y significado diferentes, fueron acercándose hasta, como veremos en seguida, ser utilizados como sinónimos en el siglo XVIII tanto entre los revolucionarios franceses como entre los «padres fundadores» americanos, independientemente de la ideología — democrática o no- de cada autor. En unos textos pueblo y nación aparecen concebidos en sentido restringido y, por tanto, aparentemente conciliable con un sufragio censitario, y en otros, ambos conceptos son utilizados en sentido amplio correspondiéndose con el sufragio universal. Así podemos apreciarlo, como veremos de inmediato, en varias voces de La Enciclopedia; así en las obras de CONDORCET; así, en el mismo SIEYÈS, que afirma en un discurso parlamentario: «Todos los poderes vienen del pueblo, es decir, de la nación»; así, en fin, en la Constitución de los Estados Unidos, hecha por «Nosotros, el Pueblo de los Estados Unidos». A ilustrarlo dedicamos las siguientes páginas,

11 PÉREZ SERRANO, N.: Tratado de Derecho Político, ob. cit., pág. 148. 
con una breve alusión a LOCKE, autor del que arrancan casi todos los «filósofos» $\mathrm{y}$ «padres fundadores».

LOCKE utiliza casi siempre el término pueblo y, si bien sostiene que el poder supremo del Estado es el legislativo, se está refiriendo a los poderes constituidos (aunque él no emplea esta expresión, sí es nítido su concepto), más allá del cual el pueblo (o la comunidad) tiene una reserva de poder (soberanía) para resistirlo y deponerlo ${ }^{12}$.

\subsubsection{Textos franceses}

\section{La Enciclopedia}

En el artículo «Pueblo», firmado por JAUCOURT, se evoca un tiempo, no sé yo si imaginado, en el que, en Francia,

«[el pueblo era] la parte más útil, la más preciosa y, en consecuencia, la más respetable de la nación».

Y a continuación se refiere a una reducción del concepto operada por cierto autor, que no nombra, quedando entendido el pueblo sólo como los obreros y los labradores ${ }^{13}$.

Prescindiendo de esta mera anécdota, que no parece que pase de ahí, resulta curioso que, según JAUCOURT, el pueblo fuera para algún autor una parte de la nación, cuando los conceptos manidos que nos han llegado son los contrarios: la nación como una parte del pueblo, también la que se entendía como más útil y respetable.

No es éste, sin embargo, el tratamiento usual que se da en esa magna obra a los conceptos que nos interesan. Rastreando por los diversos artículos que la integran, algunos incluso del mismo autor citado, puede observarse que se los entiende como mutuamente referentes, a los que se añaden en ocasiones otros términos como sociedad, comunidad y patria, sobre los que no vamos a detenernos. Veamos algunos textos:

— «Cuando el pueblo está unido a su patria... se establece una forma de

12 LOCKE: Segundo Tratado sobre el gobierno civil, passim; cfr. VARELA SUANCES-CARPEGNA, J.: «La soberanía en la doctrina británica (de Bracton a Dicey)», en la Revista Fundamentos, no 1/1998, Junta General del Principado de Asturias, págs. 106-119.

13 Artículo «Pueblo»; citado por la edición La Enciclopedia: Selección, Guadarrama, Madrid, 1970, pág. 225. 
pensamiento que se perpetúa en la nación».

- El legislador «debe consultar continuamente los deseos de la nación... debe incluso comprometer a los pueblos a ocuparse de los gobiernos, y es un medio de integrarlos en la patria».

— El sentimiento de benevolencia «es el vínculo entre él [el legislador] y su pueblo... que lo lleva a hacer brillantes sacrificios de su interés personal al interés de la nación».

— «Los pueblos, al comparar en cada nación sus leyes...» (cursivas mías).

Los cuatro pasajes se encuentran en el artículo «Legislador» ${ }^{14}$. Podemos consultar estos otros, que pertenecen, los dos primeros, al artículo «Ley» ${ }^{15}$, y el último, a «Representantes» ${ }^{16}$, ambos redactados por el propio JAUCOURT.

— «Toda ley debe ser... adecuada al gobierno del pueblo que la recibe.»

- «Sin embargo, las leyes pueden contribuir a formar las costumbres, los hábitos y el carácter de una nación».

— «Interesa, pues al soberano [se refiere al titular del ejercicio del poder] que esté representada la nación. De ello depende su propia seguridad; el afecto de los pueblos es el muro más fuerte contra los atentados de los malvados» (cursivas mías).

No se trata de los únicos pasajes, aunque sí de los más expresivos; pero la sinonimia o, al menos, la estrecha cercanía puede observarse en algunos otros ${ }^{17}$.

\section{Sieyès}

SIEYÉS, en ¿Qué es el Tercer estado? muestra una clara preferencia por las locuciones representación nacional y elección del pueblo, aunque en ocasiones habla de

14 Artículo «Legislador», citado por la edición Diderot, D'Alambert: Artículos políticos de La Enciclopedia, Altaya, Madrid, 1995, págs. 94-104.

15 Ibidem, págs. 109 y 114.

16 Artículo «Representantes», edic. de Guadarrama, cit., págs. 235-236.

17 El carácter o espíritu de una nación es una idea que MONTESQUIEU utiliza con frecuencia al paso que hace lo propio con el espíritu de las leyes. Pero JAUCOURT, que sigue continuamente al barón bordelés, juega con dicha idea y cambia frecuentemente de sujeto, al menos en apariencia, pasando de uno a otro o a un tercero o cuarto término; así, pueden verse abundantes alusiones a: el genio de los pueblos; el espíritu del pueblo; el bienestar y el genio del pueblo; el espíritu de la comunidad; el genio de los reyes y de las naciones. Los tres primeros, en el artículo «Legislador», y el último, en «Ley», ya citados. 
procuración (o comisión) del pueblo, de donde se desprende su equivalencia. En todo este importante alegato revolucionario, no diferencia pueblo y nación ni una sola vez, ni una sola, y son frecuentes los pasajes en los que se los emplea directamente como sinónimos. Sirvan dos ejemplos:

«Estas clases [las del tercer estado] no tienen otro interés que el del resto del pueblo. Ved si no contienen bastantes ciudadanos instruidos, honestos, dignos, a todos los respectos, de ser buenos representantes de la nación» ${ }^{18}$.

«Si los señores y el rey no son representantes de la nación, no son nada en el poder legislativo... Todo lo que entra en el cuerpo legislativo no es competente a votar por los pueblos sino en tanto está encargado de su procuración» ${ }^{19}$.

«De cualquier manera que sean diputados... con tal que no se pueda ignorar... que obran en virtud de una comisión extraordinaria de los pueblos, su voluntad común valdrá por la de la nación misma» ${ }^{20}$.

3. Declaración de Derechos del Hombre y del Ciudadano de 1789

a) Conforme al Preámbulo, la Declaración está hecha por los representantes del pueblo francés, constituidos en Asamblea Nacional, o bien la hace ésta en cuanto constituida por aquéllos.

b) El principio de toda soberanía, dice el artículo $3^{\circ}$, reside esencialmente en la nación.

De donde, pueblo y nación están hermanados y representados en la Asamblea Nacional; así que no parece haber entre ellos diferencia alguna que resaltar.

\section{Constitución de 1791}

Se suele atribuir el inicio de la distinción entre pueblo y nación a la Constitución de 1791, bien que en textos posteriores se volviera a veces a su indistinción $\mathrm{o}$, al menos, a una cierta oscuridad al respecto. Yo mismo he escrito en alguna ocasión que el giro hacia la segregación de los conceptos de nación y pueblo se produce en el Constitución de $1791^{21}$. Me guiaba para ello, entre otros

18 SIEYÈS: ¿Qué es el Tercer estado?, edic. cast., con introducción, traducción y notas de Francisco Ayala, Aguilar, Madrid, 1973, pág. 36.

19 Ibidem, pág. 64

${ }^{20}$ Ibidem, pág. 84.

${ }^{21}$ Cfr. TORRES DEL MORAL, A.: «Democracia y representación en los orígenes del Estado constitucional», REP, n 203, Madrid, 1975. 
indicios, por el de escribir siempre Nación con mayúscula, como concepto jurídico-político que alude al ente colectivo titular de la soberanía; y pueblo siempre con minúscula, como concepto sociológico equivalente al agregado o suma de los franceses. Debo matizar ahora que también en algunos pasajes de la primera Constitución revolucionaria esa diferencia es menos clara.

El Preámbulo, de una parte, declara que está hecho por la Asamblea Nacional, en tanto que, de otra, hace una rabiosa declaración de igualdad más propia de los movimientos demócrata-revolucionarios de mitad del siglo siguiente: no hay ni nobleza, ni pares... ni justicias patrimoniales... ni títulos, ni prerrogativas, ni órdenes de caballería... ni condecoraciones; «no existe otra superioridad que la de los funcionarios públicos en el ejercicio de sus funciones». Reparemos en el apartado quinto de esta notable pieza, que, en igual tono, dice:

«Ya no hay, para ninguna parte de la nación, ni para ningún individuo, privilegio o excepción alguna al derecho común de todos los franceses».

Donde se identifica la nación con todos los franceses, que es justo el concepto de pueblo que sostiene la doctrina dominante.

Cierto que la soberanía «pertenece a la nación», según reza el artículo $2^{\circ} .1$ del título III, pero el artículo siguiente aclara que los representantes son elegidos libremente por el pueblo, lo mismo que los jueces (mismo tit., art. $5^{\circ}$ ). La oscuridad procede del hecho de que los titulares del derecho de sufragio activo no son todos los hombres ni todos los franceses, (esto es, los integrantes del pueblo según la doctrina mayoritaria), sino los ciudadanos activos (que, siempre según esta doctrina, son los integrantes de la nación). Más aún, poco más adelante se dice que los representantes, que lo son de la nación (art. $7^{\circ}$ de la sec. IV del mismo cap. I del tít. III) prestan juramento, en nombre del pueblo francés, «de vivir libres o morir», y a continuación prestan otro de ser fieles a la nación (art. $6^{\circ}$ ).

Esta misma indistinción se produce más adelante, en la sección I del capítulo II (arts. $2^{\circ}$ y $4^{\circ}$ ), donde se regula el estatuto jurídico del Rey: su título es el de «Rey de los Franceses» (¿del pueblo francés?) y ha de prestar el mismo juramento de fidelidad a la nación y es ésta, la nación francesa (¡no los franceses!) la que contribuye al esplendor del trono financiándolo mediante una lista civil. En fin, el título VI lleva como rótulo «De las relaciones de la Nación francesa con las naciones extranjeras», en el que, siguiendo una terminología defectuosa, aunque consolidada, en este tipo de relaciones, el término «nación» es utilizado como sinónimo de Estado, acaso porque, aunque no exactamente, los Estados han terminado siendo Estados nacionales. 
En vista de lo cual considero muy arriesgado intentar extraer una conclusión científica de tan libérrimo uso de los términos que nos interesan; si acaso, la de su uso indistinto, sinonímico o sincrético. Con todo, resulta bastante evidente de nuevo que habrán de ser los sostenedores de la nítida separación conceptual de pueblo y nación los que deban asumir la carga de la prueba.

\section{Proyecto constitucional girondino de 1793}

Este Proyecto, debido en su mayor parte a la pluma de CONDORCET, contiene un Proyecto de Declaración de Derechos Naturales, Civiles y Políticos de los Hombres y otro de Constitución o Acta Constitucional. El primero dedica a la materia que estamos viendo varios preceptos breves pero muy explícitos:

El artículo 25 denomina nacional a la soberanía. Y el 27 dice: «Ella reside esencialmente en el pueblo entero, y cada ciudadano tiene un derecho igual de concurrir a su ejercicio», frase esta última en la que resuena claramente ROUSSEAU.

O lo que es igual: la soberanía nacional reside en el pueblo ${ }^{22}$, fórmula que después repiten los textos de 1795 y los más próximos a nosotros de 1946 y 1958, actualmente vigente, y fórmula que igualmente ha hecho suya nuestra Constitución de 1978, por lo cual recibió severas críticas por los mantenedores de la — valga el oxímoron- errónea ortodoxia dominante en la materia.

Termina la Declaración con un precepto, el artículo 33, que insiste en igual sentido, sólo que ahora con ocasión del problema de la reforma constitucional:

«Un pueblo tiene siempre el derecho de revisar, de reformar y de cambiar su Constitución...»

$\mathrm{Si}$, como es de común aceptación, el poder constituyente es un corolario inevitable de la soberanía, el titular de ambos debe ser el mismo, en nuestro caso, el pueblo, aunque su ejercicio se haga a través de representantes.

Por su parte, el Preámbulo de la Constitución es harto elocuente de la tesis que defendemos. Dice así:

«La nación francesa se constituye en República una e indivisible, y, fundando su gobierno sobre los derechos del hombre, que ha reconocido y declarado, sobre los principios de la libertad, de la igualdad y de la soberanía del pueblo, adopta la Constitución siguiente» (cursivas mías)

${ }^{22}$ Ya se entiende que el adjetivo entero añadido a pueblo no es más que un refuerzo, ciertamente innecesario, de los caracteres de unidad e indivisibilidad de éste. 
Se desprende que nación francesa es Francia, pero no un ente abstracto, sino el Estado francés como organización política de la comunidad nacional francesa. Equivale obviamente a decir que el Estado francés se constituye en República. Aquí no hay sinonimia entre nación y pueblo, pero no porque se manipule el concepto de nación, sino porque se lo toma en otra acepción perfectamente legítima, que sirve, mediante una sencilla sinécdoque, para llamar al Estado por uno de sus presupuestos básicos. Pero no deja de ser sugestivo que la nación funde su gobierno en la soberanía del pueblo, con lo que los dos conceptos quedan hermanados en vez de opuestos y enfrentados, como se nos quiere persuadir.

\section{Constitución jacobina de 1793}

Las expresiones relativas a la soberanía y a los sujetos de los derechos están muy mezcladas:

Tanto el Preámbulo de la Declaración de Derechos que encabeza esta Constitución (muy similar, aunque más breve, al de la Declaración de 1789) como el texto constitucional mismo optan por el sincretismo, mezclando las expresiones de un lado y de otro. Así, por lo que se refiere a la Declaración de Derechos:

a) El Preámbulo dice que la Declaración está hecha por el pueblo francés: «El pueblo francés... proclama...»

b) Los artículos 23 y 25 siguen el ejemplo del proyecto girondino. Según el primero, la garantía de los derechos reposa en la soberanía nacional, soberanía que, conforme al segundo, reside en el pueblo.

Y, en cuanto a la Constitución (llamada «Acta Constitucional»), tenemos:

c) Art. $2^{\circ} .-$ «El pueblo... para el ejercicio de su soberanía...»

d) Art. $7^{\circ}$.- «El pueblo soberano es la universalidad de los ciudadanos franceses».

e) Art. 21.- «La población es la única base de la representación nacional.

f) Art. 22.- «Hay un diputado por cada cuarenta mil individuos.»

g) Art. 29.- «Todos los diputados lo son de la nación entera.»

\section{Constitución de 1795}

Finalmente, la Constitución de 1795 no nos depara grandes novedades sobre lo ya conocido ni a lo largo de su articulado ni en la Declaración de Derechos que la preside. No se diferencia, pues, entre pueblo y nación ni entre sus respectivas titularidades de la soberanía. 
Cuando estos dos términos aparecen separados en sendos artículos no se diferencia su concepto. En efecto, acaso por un prurito literario y refiriéndose al futuro, dice en su artículo 374: «La nación francesa declara...», en tanto que en el 377 puede leerse: «El pueblo francés deja en depósito la presente Constitución...». Como es obvio, no podemos deducir de ahí la existencia de unas funciones propias de la nación y otras del pueblo. Realmente, no lo son ni de aquélla ni de éste, sino compromisos que los poderes públicos deben asumir y cumplir como mandatos constitucionales.

\subsubsection{Textos americanos}

1. Desde la Independencia hasta la Constitución federal

Los textos que jalonan el tránsito de las antiguas colonias británicas de América a su independencia hasta la formalización de la Unión nos ayudan a salir de dudas, si las hubiere. Desde la Declaración de Derechos del Congreso de Nueva York, de 19 de octubre de 1765, hasta la Ordenanza para el gobierno del Territorio de Estados Unidos al Oeste del Río Ohio, de 13 de julio de 1787, no encontramos ni uno solo pasaje que diferencie pueblo y nación. Bien de un modo directo o por vía indirecta o perifrástica atribuyen $\longrightarrow$ mejor, reconocencomo titular del poder al mismo sujeto con denominaciones intercambiables, aunque con la presencia constante del término pueblo. Veamos esas expresiones:

1) El pueblo, o el buen pueblo de..., y aquí el nombre de la colonia o Estado correspondiente, o el (buen) pueblo de esta(s) colonia(s) ${ }^{23}$.

2) El pueblo (o el buen pueblo) de América ${ }^{24}$.

Junto a las anteriores locuciones, pero de modo más radical, algunos de estos documentos se refieren al titular originario (término que sería utilizado en los primeros debates constituyentes españoles aunque finalmente no apareciera en el texto constitucional gaditano):

3) Todo gobierno de Derecho tiene su origen en el pueblo (o fórmula similar $)^{25}$.

${ }^{23}$ Así, por ejemplo, en las Declaraciones de Derechos de Virginia y Delaware, y en las Constituciones de Georgia, Carolina del Norte, Nueva York, Vermont, Carolina del Sur y Nueva Hampshire.

${ }^{24}$ Constituciones de Georgia y de Nueva York.

${ }^{25}$ Constituciones de Maryland, y Vermont; Declaración de Derechos de Carolina del Norte. 
4) Todo el poder ha vuelto al pueblo (en clara referencia a la situación colonial anterior $)^{26}$.

5) Todo el poder reside, o radica, en el pueblo, y se ejerce por la autoridad el pueblo $^{27}$.

6) El pueblo (o el pueblo y la comunidad) tiene derecho a gobernar, a gobernarse; también tiene derecho (o derecho y obligación) de cambiar el gobierno, (o deponerlo, o abolirlo, o «arrojarlo fuera») ${ }^{28}$.

7) Tiene también derecho a disolver los lazos políticos que lo han conectado con otro, de nuevo en alusión a la anterior situación de dependencia colonial $^{29}$.

8) El poder es responsable ante el pueblo $^{30}$.

9) El pueblo de esta comunidad tiene el único, exclusivo inherente, incontestable, inalienable e inapelable derecho gobernarse, o de gobernar y regular su gobierno, o de constituir gobierno ${ }^{31}$.

10) El pueblo acuerda constituirse en un cuerpo político o Estadio libre, soberano e independiente ${ }^{32}$.

11) $\mathrm{O}$, en fin, con rotundidad y belleza literaria: el pueblo es «principio y fin de todos los gobiernos» ${ }^{33}$.

¿Y la nación? Este término aparece poco, pero, cuando lo hace, va unido al de pueblo y, en alguna ocasión, al de comunidad. Así, en el Preámbulo de la Declaración de Derechos de Virginia puede leerse:

«Que el pueblo se constituye, o debiera constituirse, para el beneficio común, la protección y la seguridad del pueblo, nación o comunidad» (people, nation or community)

Frase extraordinariamente significativa para nuestro propósito, que se repite literalmente en las Constituciones de Vermont de 1777 y 1786. Por cierto que, de forma coherente con esta sinonimia, la Declaración virginiana atribuye a la co-

${ }^{26}$ Constitución de Nueva York.

27 Constituciones de Nueva York, Massachusetts, Nueva Hampshire y Vermont.

28 Declaración de Independencia, Constituciones de Pensilvania, Nueva York, Vermont y

Nueva Hampshire; la Declaración de Derechos de Virginia dice lo mismo de la comunidad.

${ }^{29}$ Constitución de Nueva York.

30 Constitución de Vermont.

31 Declaración de Derechos de Carolina del Norte, Constituciones de Massachusetts, Nueva Hampshire y Vermont.

32 Constitución de Nueva Hampshire.

33 Declaración de Derechos de Virginia. 
munidad «el indiscutible, inalienable e irrevocable derecho a reformarlo [al gobierno\}, alterarlo o abolirlo».

Consiguientemente, tampoco podemos esperar de los textos mentados del otro lado del Atlántico una clave segura para diferenciar los conceptos de pueblo y nación en los orígenes del Estado constitucional y representativo. La distinción, si existió alguna vez, habrá de ser buscada en otras fuentes.

\section{Constitución federal de los Estados Unidos}

«Nosotros, el Pueblo de los Estados Unidos... establecemos y sancionamos esta Constitución».

Así reza su memorable Preámbulo, en tanto que el término pueblo es reiterado en el artículo $1^{\circ}$ sección $2^{\mathrm{a}}$ : «el pueblo de los diversos Estados».

En el texto constitucional propiamente dicho, el aprobado en 1787, no se registra ninguna otra locución igual ni contrapuesta. Es utilizado de nuevo el término pueblo en las enmiendas, pero sólo una vez como sujeto político; es en la enmienda $10^{\mathrm{a}}$ :

«Las facultades que esta Constitución no delega a los Estados Unidos ni prohỉbe a los Estados quedan reservadas a los respectivos Estados o al pueblo» (cursica mía).

\section{El Federalista}

En los artículos de El Federalista no se plantea la cuestión: se utiliza casi siempre la voz pueblo y el origen popular de todo poder. A su vez, los términos nación y nacional son usados en contraposición a federación y federal; es decir, nación hace referencia a la Unión como un todo, a todo el pueblo de los Estados Unidos, que es el que, conforme al Preámbulo de la Constitución, ejerce el poder constituyente. En alguna ocasión, sin embargo, MADISON, bajo el pseudónimo de Publius, viene a darle otro empleo: «La Constitución ha de basarse en la conformidad y en la ratificación del pueblo de América..., pero... debe darla el pueblo no en su condición de individuos que componen una sola nación, sino como componentes de los distintos e independientes Estados». Texto en el que se detectan dos conceptos de pueblo: la suma de individuos de toda la Unión y esos individuos en cuanto integrantes de los distintos Estados ${ }^{34}$.

${ }^{34}$ MADISON: Artículo n 39 de El Federalista, edic. cast. Fondo de Cultura Económica, México, 1987, pág. 161: he preferido la traducción de la edición Artículos federalistas y antifederalistas, Alianza, Madrid, 2002, pág. 106. 


\section{CIUDADANÍA Y CIUDADANÍA ACTIVA COMO CONCEPTOS CLAVES}

La diferencia no reside en los conceptos de pueblo y nación, sino en el de ciudadano, en el derecho de ciudadanía. Es decir: no se trata de que la legislación y los pensadores demócratas prefieran las expresiones de pueblo y soberanía popular, en tanto que los menos demócratas opten por las de nación y soberanía nacional, sino de que unos y otros utilizan indistintamente tales expresiones pues ambas aluden igualmente al conjunto de los ciudadanos; pero los primeros entienden por ciudadanos todas las personas, mientras que los segundos restringen su significado a sólo unas pocas, bien por razón de su renta, de su rango, de su cargo o de sus estudios.

Aun así, es preciso dejar constancia de la pluralidad de términos utilizados como sujetos de los derechos y de su no siempre fácil deslinde.

\subsection{Textos doctrinales y jurídicos}

\subsubsection{Textos franceses \\ 1. La Enciclopedia}

En los documentos revolucionarios no aparece el término súbdito, frente a lo que veremos en los textos americanos ligeramente anteriores. Pero hasta hacía bien poco, los conceptos de ciudadano y súbdito no estuvieron muy distanciados, incluso eran utilizados frecuentemente de modo indistinto. Es lo que puede apreciarse nítidamente en la Enciclopedia. Veamos algunas muestras.

JAUCOURT, redactor de los artículos «Ciudadano», «Súbdito»y «Legislador» (este último sin firma), llama la atención acerca de la incorrección del uso indistinto de esos dos términos, como le sucede a HOBBES ${ }^{35}$. Pero él mismo desliza frases en las que no se sabe si está incurriendo en igual error o es que los conceptos aún no estaban suficientemente definidos, como, cuando dice, en el tercero de los artículos citados, que «la fuerza real está en los súbditos», afirmación que sólo tiene sentido referida a los ciudadanos ${ }^{36}$.

Más gráficamente, en la voz «Soberanos», de la misma obra, también sin firma, la sinonimia se impone. Ejemplo:

«Lo que hace a los ciudadanos desgraciados es la usurpación manifiesta y la restricción de los derechos a los que el hombre jamás ha podido renunciar. El soberano está obligado a prestar seguridad a sus súbditos» (cursivas mías);

35 Artículo «Ciudadano», edic. de Altaya, cit., págs. 16-17.

36 Artículo «Legislador», edic. de Altaya, cit., pág. 95. 
Pasaje en el que los términos ciudadano, hombre y súbdito parecen manifiestamente intercambiables. Y poco después continúa el mismo artículo:

«Los jefes de las naciones que trabajan para la felicidad de sus súbditos...» (cursiva mía $)^{37}$.

Y, por no alargar más este recorrido por las páginas de la obra acaso más significativa de la Ilustración francesa, en la voz «Autoridad política», sin firma una vez más, pero seguramente escrito por el mismo JAUCOURT, podemos leer lo siguiente:

«En cuanto a los súbditos, la primera ley... es la de respetar ellos mismos las condiciones del contrato que han hecho» (cursiva mía) ${ }^{38}$,

frase directamente ininteligible si por súbdito no entendemos ciudadano, como corresponde a los sujetos pactantes y creadores de la comunidad política.

Por lo demás, si todavía permanecía una cierta indistinción entre los dos términos referidos, la indeterminación desaparece cuando se aborda el problema de la participación real y efectiva en la vida política del país, bien como elector, bien como elegible y partícipe directo en la gobernación. Instalados en este terreno, hay que introducir una clara corrección a lo indicado hasta ahora.

JAUCOURT se hace eco de MONTESQUIEU, como era su costumbre, para poner al pueblo en su sitio:

«El pueblo es muy apto para elegir a quienes debe confiar una parte de su autoridad (...) Sin embargo, así como la mayor parte de los ciudadanos, que poseen bastante capacidad para elegir, no la tienen para ser elegidos, de la misma manera el pueblo, que posee bastante competencia para enjuiciar la competencia de los otros, no es, en cambio, apto para actuar por sí mismo, ni para llevar a cabo los asuntos...» ${ }^{39}$ (cursivas mías).

Se está apostando obviamente por el gobierno representativo, en el que se distingue entre quiénes son electores y quiénes pueden ser elegidos:

«... el soberano imparcial debe escuchar las voces de todos sus súbditos... Mas, para que los súbditos se expliquen sin tumulto, conviene que tengan representantes, es decir, ciudadanos más iluminados que los otros, más interesados en el asunto, cuyas posesiones los liguen a la patria, cuya posición les permita comprender las necesidades del Estado, los abusos que en él se introducen y los remedios que conviene poner» (cursivas mías).

37 Artículo «Soberanos», edic. de Altaya, cit., págs. 197-199.

38 Artículo «Autoridad política», edic. de Guadarrama, cit., pág. 44.

39 Artículo «Democracia»; edic. de Altaya, cit., págs. 26-27. 
Distinción sumamente interesante: ciudadanos, en sentido amplio, lo son todos, equivaliendo a súbditos. Pero hay unos ciudadanos especialmente preparados para gobernar en representación de aquéllos (o, mejor, de todos). Se está incorporando, como rectificación del principio de soberanía popular o nacional, el concepto de ciudadanía activa por contraposición a la ciudadanía a secas o ciudadanía pasiva.

Esta distinción aún habría de experimentar nuevos recortes cuando se considere que ni siquiera para elegir están capacitados todas las personas integrantes de la comunidad política. Es entonces cuando tiene sentido la diferencia entre súbdito y ciudadano. Ciudadanos son los miembros de la comunidad que pueden ser elegidos o, al menos, elegir (funciones para las que, a su vez, se suelen requerir condiciones diferentes). Súbditos son los demás, los que no son más que gobernados. Y todavía hay diversos grados en esta categoría, según estemos en un gobierno representativo o ni siquiera en él, sino en un régimen despótico, al cual no voy a dedicar ni una sola página de este estudio.

\section{Declaración de Derechos de 1789}

Frecuentemente se sostiene que esta declaración distingue entre los derechos del hombre y los del ciudadano. El sujeto de los primeros sería toda persona y el de los segundos sólo quienes tuvieran la condición de ciudadano, lo que excluiría a los extranjeros residentes o transeúntes, así como a aquellas otras personas que por disposición de la ley no la hubieran alcanzado (los menores, la mujer por aquel entonces) o la hubieran perdido (los condenados a ciertas penas, los afectados por ciertas discapacidades).

No debemos incurrir, sin embargo, en la fácil crítica que algunos hacen de este texto sagrado del constitucionalismo como discriminatorio y conservador. De un lado, el droit de cité, los derechos de ciudadanía, eran fundamentalmente los de participación política y acceso a los cargos públicos; de otro, estas restricciones y diferencias estaban en el ambiente cultural de la época y sería anacrónico pretender que un texto del siglo XVIII sea tan avanzado e igualitario como otro del XXI, además de que algunas de las exclusiones comentadas continúan en vigor en los actuales regímenes demoliberales.

Por lo que se refiere al sujeto de los derechos, tenemos las siguientes variantes:

a) Diversos preceptos de la Declaración señalan al hombre, con este término o con otro equivalente. Así:

a.1) art. $1^{\circ}:$ «Los hombres nacen y permanecen libres e iguales en derechos»;

a.2) art. $2^{\circ}$ : «derechos naturales e imprescriptibles del hombre»; 
a.3) art. $3^{\circ}$ : «derechos naturales de cada hombre», «miembros del cuerpo social»;

a.4) art. $7^{\circ}:$ «Ningún hombre puede ser acusado...»;

a.5) art. $9^{\circ}:$ «Todo hombre».

a.6) en su vertiente negativa, los artículos $8^{\circ}, 10$ y 17 utilizan el término: «nul», «nadie»: «nadie puede ser castigado...», o importunado, o privado...).

b) Otras veces unen los términos hombre y ciudadano; por ejemplo, en el segundo punto del Preámbulo: «...los siguientes derechos del hombre y del ciudadano».

c) Sólo en unos pocos supuestos se habla sólo del ciudadano, justamente en el artículo $6^{\circ}$, que le reconoce el derecho de concurrir a la formación de la ley y acceder al los cargos públicos, y en los artículos 13 y 14, en los que se designa a los ciudadanos como los únicos sujetos del deber de contribución a los gastos públicos, lo que les da derecho a comprobar la necesidad de tal contribución, a autorizarla y a supervisar su gestión.

d) Curiosamente, el artículo 11 hace del hombre el sujeto del derecho de comunicación pública, y al ciudadano el sujeto del derecho a hablar, escribir, etcétera, cuyo ejercicio puede generar responsabilidad. Es ininteligible que los hombres puedan comunicarse, pero no hablar ni escribir y que no sean responsables todos los hombres, sino sólo los ciudadanos. Se trata obviamente de un recurso literario por no repetir siempre la misma fórmula.

e) Como también es una simple y algo tosca manera de hablar (de escribir, en este caso) la identificación de la sociedad como sujeto del derecho a pedir a todo agente público cuentas de su administración (art. 15). Más que de un derecho - la sociedad no es sujeto de ninguno - se trata de un mandato a los poderes públicos para que ejerzan los controles recíprocos que el Ordenamiento disponga. Y en lo que podría tener de derecho, su ejercicio correspondería a los ciudadanos o a sus representantes.

Así, pues, del anterior análisis y con las salvedades hechas, resulta inviable ver en la Declaración una diferencia clara entre los conceptos de hombre y ciudadano en todos sus preceptos. Menos aún podemos extraer de esta Declaración conclusiones acerca de su alineación con una de las dos corrientes de pensamiento que la doctrina mayoritaria cree ver en los pensadores y textos jurídicos (constitucionales o no) que jalonan el cambio del Antiguo al Nuevo Régimen: la del liberalismo conservador y la radical demócrata. Como tampoco se la puede identificar con uno de los «jefes de fila» (MONTESQUIEU o ROUSSEAU) de esas dos corrientes de pensamiento. 


\section{Constitución de 1791}

En esta Constitución, además de diferenciarse entre bombre y ciudadano como sujetos de los derechos, inmediatamente se crea otra categoría: la de ciudadano activo. Para alcanzar este derecho de ciudadanía activa era necesario cumplir requisitos adicionales a los del simple ciudadano, como tener una edad superior a la simple mayoría de edad civil, no estar incurso a una causa de exclusión, no ser servidor doméstico a sueldo y, lo que es más relevante, acreditar el pago de una contribución directa por el valor, como mínimo, de tres jornales ${ }^{40}$. Solamente estos ciudadanos activos podían ser nombrados electores, para lo cual era preciso, además, ser propietario, o usufructuario, o arrendatario de unas determinadas características $^{41}$.

Estamos ante el fundamento económico del sistema representativo que esta misma Constitución adopta: «La Constitución francesa es representativa» ${ }^{42}$.

Uno podría esperar que esa toma de posición se correspondiera con la diferenciación de los conceptos de nación y pueblo que la unánime doctrina atribuye a esta línea política, pero no es así, o, al menos, no lo es de modo indudable.

\section{Proyecto constitucional girondino de 1793}

El Proyecto de Declaración de Derechos de esta Constitución que no pasó del intento utiliza preferentemente el término ciudadano como sujeto de los derechos, pero no faltan otras expresiones, como los hombres, todo hombre, miembros de la sociedad, nadie, todos, sin que sea factible deducir la preferencia de unos cuando se trata de derechos políticos y de otros en relación con los derechos naturales y civiles. Más bien parece moverse en un cierto sincretismo. Así, por ejemplo:

- El artículo1 ${ }^{\circ}$ del Proyecto de Declaración de Derechos habla de «los derechos naturales, civiles y politicos de los hombres».

- Si bien, como hemos señalado, son los ciudadanos los admisibles a los empleos y funciones públicas (art. $9^{\circ}$ ), el mismo término es utilizado para decir que debe obedecer a la autoridad (art. 13), expresión que no puede entenderse sino viendo en el término ciudadano el equivalente a persona,

40 Tít. I, cap. I, sec. II, art. $2^{\circ}$.

${ }^{41}$ Mismos tít., cap. y sec., art. $7^{\circ}$.

42 Tít. III, art. $2^{\circ} .2$. Repárese, en todo caso, en que el precepto citado utiliza el término Constitución en el sentido de sistema o forma política, puesto que su literalidad, en caso de que interpretáramos por Constitución una norma, es ininteligible: las normas no son representativas en el sentido técnico-jurídico. 
a individuo. Y ciertamente las dos expresiones, ciudadano e individuo aparecen juntas en el artículo 28:

«Ninguna reunión de ciudadanos y ningún individuo pueden atribuirse la soberanía, ejercer ninguna autoridad ni desempeñar ninguna función pública sin una delegación formal de la ley»,

en el que inmediatamente se colige que, por razones de simple estilo literario, se ha optado por llamar de modo diferente a las personas según estén reunidas o no, sin más connotaciones jurídicas ni políticas.

El Proyecto de Constitución es más preciso. Su artículo $8^{\circ}\left(1^{\circ}\right.$ del título II) establece las condiciones para ser ciudadano. Dice así:

«Todo hombre de veinticinco años cumplidos, inscrito en el cuadro cívico de una asamblea primaria y con residencia francesa ininterrumpida de un año es ciudadano de la República» (traducción y cursivas mías).

Con no muy buena técnica jurídica, el artículo $10^{\circ}\left(3^{\circ}\right.$ del mismo título) reconoce el derecho de sufragio a los ciudadanos que cumplan tales condiciones, cuando en realidad no hay otros. Y el artículo 16 ( $9^{\circ}$ del título II) añade la edad de 25 años como condición de elegibilidad.

Otros preceptos del mismo título disponen las causas de incapacidad y de suspensión temporal para el ejercicio de dicho derecho, así como las de pérdida de la ciudadanía, que veremos al estudiar las establecidas por la Constitución gaditana. Por último, es igualmente coherente que en todo el título indicado, que tiene como rótulo «Del estado de los ciudadanos y de las condiciones necesarias para ejercer los derechos», el término empleado sea este de ciudadano.

\section{Constitución jacobina de 1793}

Al tratar de la soberanía, ya hemos anticipado algunos rasgos de esta Constitución (con su correspondiente Declaración de Derechos), que son interesantes para el objeto del presente epígrafe; entre otros, su marcada preferencia por el término pueblo sobre el de nación, pero mezclándolo con el de ciudadanos, concepto que la Declaración de Derechos, en la mayoría de los casos, no diferencia nítidamente del de hombre como sujetos de derechos,

Pero en alguna ocasión, e importante, sí lo hace. Así, lo primero sucede en pasajes como los siguientes: 
1. La Declaración la hace el pueblo francés, decidido a no olvidar los derechos naturales del hombre «a fin de que los ciudadanos puedan comparar...» (Preámbulo).

2. «Todos los hombres son iguales por naturaleza y ante la ley» (art. $\left.3^{\circ}\right)$.

3. En cambio, el artículo $5^{\circ}$ afirma: «Todos los ciudadanos son igualmente admisibles a los empleos públicos» (subrayados míos).

Y sucede lo segundo, esto es, una cierta indistinción en pasajes como los siguientes:

- «Todo ciudadano... prendido por la autoridad de la ley debe obedecer al instante» (art. 10), lo que, como hemos dicho respecto del documento anterior, se supone en buena lógica que debe hacer todo individuo.

- Según el artículo 16, todo ciudadano tiene derecho a la propiedad. De nuevo hay que entender que aquí ciudadano es igual a persona o individuo.

- El artículo siguiente dispone que ninguna clase de trabajo, de comercio, etcétera, puede prohibírsele a los ciudadanos, a lo que cabe hacer igual comentario.

- La sociedad debe subsistencia a los ciudadanos desafortunados, dice el artículo 21. Es bien claro que aquí ciudadanos no significa, como en otros textos liberales doctrinarios, ni persona con estudios, ni propietario, ni miembro de la aristocracia, etcétera, que serían precisamente los que menos necesitarían del socorro público, sino persona.

- «La instrucción es una necesidad para todos. La sociedad debe poner la instrucción al alcance de todos los ciudadanos» (art. 22). Evidentemente, se refiere a toda persona, porque se trata de una necesidad de todos.

Por lo que se refiere al Acta Constitucional, vuelve a haber preferencia, ahora de una manera más decidida, por el término ciudadano a la hora de reconocer derechos políticos:

El pueblo está integrado por la universalidad de los ciudadanos franceses. Y es a este pueblo, a esta totalidad ciudadana a la los que se circunscribe el nombramiento inmediato (esto es, directo) de sus diputados (art. $7^{\circ}$ ). Y, al contrario de los textos anteriores, no exige requisitos añadidos para lo segundo (arts. 5 y 29 de la Declaración de Derechos y 28 del Acta Constitucional).

Ahora bien, ¿quiénes son ciudadanos? De manera más coherente y, sobre todo, más democrática ${ }^{43}$ que los textos anteriores, la Constitución jacobina no

${ }^{43}$ Bien distinta por cierto del ulterior ejercicio del poder por parte de los sus autores, los jacobinos. 
exige condiciones especiales para ser ciudadano, sino las comunes de masculinidad, edad (21 años), domiciliación francesa durante un año. En cuanto a los extranjeros, sólo se les exigía, además, el cumplimiento de otro requisito de entre los cinco siguientes: vivir de su trabajo, adquirir una propiedad, casar con francesa, adoptar un hijo o tener a su cargo un anciano. Por último, también ejercen los derechos de ciudadanía los extranjeros que lo merezcan a juicio del Cuerpo Legislativo (art. $4^{\circ}$ del Acta Constitucional).

Derechos de ciudadanía que se pueden perder o pueden ser suspendidos $\left(\right.$ arts. $5^{\circ}$ y $\left.6^{\circ}\right)$, como veremos con ocasión del estudio de la Constitución española de 1812 .

5. Constitución de 1795

a) La Declaración de Derechos que la encabeza dice de sí misma que es proclamada por el pueblo francés; repite que la soberanía reside esencialmente en la universalidad de los ciudadanos (art. 17) y da entrada a la participación directa de los ciudadanos además de la representativa (art. 20).

b) En el texto constitucional propiamente tal encontramos pocos pasajes que resaltar, salvo que reitera la fórmula antedicha de la residencia de la soberanía, pero, de modo semejante a como hizo el texto jacobino, aclara que ciudadanos lo son todos los franceses y admite a la ciudadanía a algunos extranjeros (arts. $2^{\circ}$ y $8^{\circ}$ a $10^{\circ}$ ), no existiendo más superioridad entre ellos que la de los funcionarios públicos en relación con el ejercicio de sus funciones (art. 351).

\subsubsection{Textos americanos}

a) Hasta la Constitución federal de 1787

En los textos originarios americanos, sean Declaraciones de Derechos, sean Constituciones, todas las cuales dicen haber sido hechas por sus respectivos pueblos o por sus representantes, no hay ni asomo del derecho universal de sufragio, no ya cuando identifican el titular de la soberanía con el solo término de pueblo, sino tampoco cuando se le adicionan los de comunidad o nación; ni siquiera podemos obtener un vago indicio de que en el futuro pudiera ser así. Conviene asomarse a estos documentos para ver el tratamiento que se da a este punto. 
a) Los términos o expresiones más usuales para aludir al sujeto de los derechos en general son: hombre, todos los hombres, persona, individuo, habitantes de esta colonia, de este Estado), miembros de este Estado (de la sociedad o de la comunidad), colonos (colonits), ciudadanos libres (freemen). Y, en forma negativa: nadie, ninguno... puede ser privado de... Algún documento habla de americanos ${ }^{44}$.

b) Es llamativa, por otra parte, la consideración - técnicamente muy defectuosa - del pueblo como sujeto de algunos derechos, como los de libertad de expresión, reunión o el de portar armas ${ }^{45}$.

c) Y no deja de ser reseñable, porque afecta directamente al objeto de este estudio, que ciertos documentos empleen, junto a algunas de las anteriores expresiones, la de súbditos (subjetcs), o ambas, incluso la de co-súbditos (fellow subjects) y súbditos libres (free subjetcs) ${ }^{46}$; lo cual posiblemente sorprenderá al lector desprevenido. Todo ello sin perjuicio de que el primero de esos dos documentos se exprese en términos inequívocos acerca del pueblo como titular de la soberanía: "todos los poderes del gobierno se ejercen por la autoridad del pueblo de las colonias». En realidad, esas locuciones de súbdito, como también la de vasallo, que hoy producen, no sin razón, un abierto rechazo en la cultura europea continental, eran usuales en la época, y más aún en la cultura británica, en la que incluso en la actualidad se usan sin desdoro ni pudor.

Cuando se regula o se alude en estos documentos a la participación política, se establecen de modo invariable condiciones para ello o se da entrada al sujeto titular de este derecho, distinto del genérico «todos los hombres, personas o individuos». Estamos ante un sujeto diferente singularizado respecto de los demás:

1) las condiciones suelen ser las de ser propietario y tener cierta cantidad de dinero en moneda oficial (que todavía era la libra) o en bienes reales y personales en el mismo condado;

2) o bien se lo identifica con el freeman, hombre libre, que era precisamente el que reunía tales condiciones;

3) o, como hace la Declaración de Derechos de Virginia, se traza un perfil del mismo ("todos los hombres que prueben suficientemente tener un interés permanente en la comunidad y adbesión a ella») que, si no equivale exacta-

44 Concretamente la Declaración de Derechos del Congreso Continental (1774).

45 Así puede leerse en las Constituciones de Pensilvania, Massachusetts, Nueva York, y Vermont (1777 y 1786).

46 Declaraciones de Derechos del Congreso de Nueva York, de 1765, y del Congreso Continental, de 1774. 
mente al freeman, al hombre libre propietario o con cierta renta, apunta a él, como así fue de hecho;

4) por último, mientras unos textos declaran, ora en sus preámbulos, ora en sus articulados, que están redactados o acordados por los representantes o por los mandatarios del pueblo, otros emplean locuciones más directas y explícitas:

— «representantes de los freemen» ${ }^{47}$;

- delegados de los freemen ${ }^{48}$;

- o bien se dispone que la Cámara de Representantes de los Freemen estará integrada por personas elegidas «por los freemen de cada ciudad y condado de esta comunidad» ${ }^{49}$.

b) Constitución federal

En el texto constitucional de primer cuño se detectan pocos términos referidos a los sujetos de derechos, pues sabido es que éstos están reconocidos en las subsiguientes enmiendas, las cuales sí son más expresivas al respecto. Así, pues, encontramos:

1. En cuanto a derechos civiles:

- persona

- ciudadano; curiosamente, la enmienda $11^{\text {a }}$ lo une al de súbdito cuando se refiere al extranjero: «... por ciudadanos de otro Estado o por ciudadanos o súbditos de cualquier Estado extranjero»

- pueblo (al cual, lo mismo que en algunos textos de la fase de independencia y confederal, se le reconoce, con una técnica jurídica nada depurada, como sujeto de los derechos a reunirse, a poseer y llevar armas y a la seguridad de sus personas (enmiendas $1^{\mathrm{a}}, 2^{\mathrm{a}}$ y $4^{\mathrm{a}}$ ).

2. Y, por lo que se refiere a los derechos políticos, encontramos prácticamente los mismos términos:

- de nuevo persona y ciudadano;

— el indefinido quien: «No podrá ser senador quien...» (art. $1^{\circ}$, sec. $3^{\mathrm{a}}$, apdo. 3, y enm. $14^{\mathrm{a}}$, sec. $3^{\mathrm{a}}$ );

- y otra vez pueblo, en una clara sinécdoque, como conjunto de los ciudadanos: «dos senadores por cada Estado, elegidos por el pueblo...» (enm. 17 ${ }^{\mathrm{a}}$ ).

47 Constitución de Carolina del Norte, Constitución de Vermont. 1777.

48 Declaración de Derechos de Maryland.

49 Constitución de Pensilvania. 


\subsection{Conclusión}

En primer lugar, hay que convenir en que en este problema terminológico, que nunca es meramente terminológico, se ha incurrido con frecuencia en anacronismos, consistentes en inyectar en textos de otra época significados de la nuestra; incluso podemos decir que ni siquiera dentro de la misma época histórica coinciden las terminologías usuales en dos culturas más bien semejantes, como la americana y la europea. En estas cuestiones no vale el vale todo; es preciso el bisturí del análisis y no el ojo de buen cubero.

De ninguno de los textos aducidos, tanto franceses como americanos, a los que cabría añadir algunos otros, pueden inferirse dos conceptos diferentes, menos aún encontrados, de pueblo y nación, como la doctrina casi unánime recibida da por supuesto sin el más mínimo análisis. Antes bien, se pone de relieve la fungibilidad de los mismos.

La diferenciación entre pueblo y nación no existe en los pensadores políticos ilustrados, es titubeante y poco precisa en la legislación constitucional revolucionaria y tampoco aparece en los textos norteamericanos. En cuanto a estos últimos, la Constitución federal sólo emplea pueblo, y los textos anteriores, que en alguna ocasión utilizan también el término nación, lo hacen precisamente en clara sinonimia con el de pueblo. No faltan pasajes en la Francia revolucionaria que dicen que la soberanía nacional reside en el pueblo, o en el pueblo entero.

Únicamente en la Constitución de 1791 existe una decidida distinción entre hombre, ciudadano y ciudadano activo, reservando a éste, que sólo puede serlo si cumple ciertas condiciones económico-censitarias, el derecho activo y pasivo de participación política. Pero, para que ni siquiera en este caso quede todo nítido, recordemos que en el artículo $1^{\circ}$ del título III puede leerse:

«La soberanía... pertenece a la Nación; ninguna sección del pueblo ni ningún individuo puede atribuirse su ejercicio» (cursivas mías),

En donde no queda nada claro si una sección del pueblo lo es de la nación o no, ni si ese individuo es, aunque no se diga así, un ciudadano individual (que es el único que podría generar alguna expectativa ejercer la soberanía), o un individuo del común, que es lo que se dice literalmente, pero se dice mal, haciendo ininteligible la frase.

La manipulación de los términos y de sus respectivos conceptos se ha hecho aislando textos de su contexto, principalmente en las Constituciones francesas de 1791 y 1793 (jacobina). En efecto, como ya hemos señalado, en la primera aparece Nación con mayúscula, como concepto jurídico-político que alude al ente colectivo titular de la soberanía; y pueblo siempre con minúscula, como concepto so- 
ciológico equivalente al agregado o suma de los franceses. Y sobre ese escuálido fundamento se montó la teoría de «las dos soberanías».

Ahora bien, como el jacobinismo se reclamaba de ROUSSEAU, al menos en ciertas cuestiones, y prefería hablar de soberanía del pueblo en vez de soberanía de la nación, un notable teórico del Estado, como CARRÉ DE MALBERG, bien secundado por sus discípulos, extrajo de ahí la teoría diferenciadora que expusimos en páginas anteriores. Las dos líneas teórico-ideológicas parecían claras: una primera iba de LOCKE a MONTESQUIEU, a la Constitución de 1791, al sufragio censitario y al constitucionalismo doctrinario decimonónico; la segunda, de LOCKE a ROUSSEAU, al jacobinismo y «su» Constitución de 1793, al sufragio universal y a los movimientos democráticos del siglo XIX.

Tal ejercicio teórico es brillante y por eso ha sido secundado por la generalidad de la doctrina constitucionalista europea, pero, al, mismo tiempo, es sumamente incorrecto.

En puridad, salvando algún pasaje, el empleo del término Nación con mayúscula en las Constituciones francesas revolucionarias equivale más bien a Francia. Nación francesa es Francia; pero no una abstracta Francia eterna; tampoco es la síntesis de su Historia, su arte, su lengua, su religión, sus muertos, sus generaciones futuras, sus propietarios, sus comerciantes y sus funcionarios. Es la comunidad política integrada por franceses, es el Estado francés. Y su soberanía es la soberanía de ése Estado ad extra, en las relaciones internacionales.

Tendríamos así dos significados complementarios que no siempre se tienen en cuenta a la hora de interpretar estos pasajes:

1) La soberanía de Francia en las relaciones internacionales corresponde a la Nación en cuanto comunidad política constituida en Estado.

2) Y hacia dentro, la corresponde a la Nación en cuanto conjunto de todos los franceses

Por su parte, la Constitución jacobina nos ofrece el término que faltaba, población, de indisimulable carácter sociológico y, en este caso, cuantitativo: la base poblacional de la representación significa que, a estos efectos, el pueblo francés es representado según una razón aritmética: justamente la de un diputado por cada 40.000 individuos. Pero debemos de subrayar de nuevo que, si la representación es nacional, y todos los diputados representan a la nación entera, ésta, la nación, tampoco es algo intemporal ni abstracto, sino que está integrada por individuos, lo mismo que se suele decir del pueblo. De manera que, cuando se quiere diferenciar entre pueblo y nación, lo que se está haciendo es confundir el concepto jurídicopolítico de pueblo con el concepto sociológico de población.

En todo caso, la semilla de la inflexión semántica terminó arraigando. El liberalismo conservador, algunas de cuyas versiones, como el liberalismo doctri- 
nario, seguían teniendo un pie en el Antiguo Régimen, se adueñó del concepto restringido de Nación, lo mixtificó, lo mitificó y lo mistificó, haciendo de la Nación una realidad abstracta. Nación francesa era la Francia eterna, pero con pocos franceses vivos. De esa manera, se pudo hablar de soberanía nacional en algunas Constituciones decimonónicas en tanto que, mediante el establecimiento del sufragio censitario, se excluía del ejercicio de la soberanía a la mayor parte de la nación real ${ }^{50}$. Todo lo cual lastró buena parte del constitucionalismo francés y europeo y un siglo del constitucionalismo español.

A esta manipulación y mistificación los movimientos sociales de mediados del siglo XIX y decenios siguientes opusieron otra mística: la del pueblo bumilde y soberano que reclama y conquista, a veces mediante la fuerza y la sangre, el sufragio universal. La justicia de esta reivindicación no puede hacernos desconocer que con tal argumentación se daba por bueno el concepto manipulado de nación y, desde entonces, ambas ideas han aparecido teórica y prácticamente como irreconciliables.

Pero hoy en día, cuando el sufragio universal se ha enseñoreado de los regímenes demoliberales, sostener esta diferenciación es un verdadero desatino, pues equivale a renunciar a unas expresiones nobles (nación, soberanía nacional; también ha ocurrido con la palabra patria) y entregárselas a los enemigos de la democracia, que aparecen así como los únicos «nacionales» y patriotas. Pero además de un desatino político es, como hemos podido comprobar, un error científico.

\section{LA SOBERANÍA NACIONAL/POPULAR EN LA CONSTITUCIÓN ESPAÑOLA DE 1812}

\subsection{Previa mirada panorámica al constitucionalismo bistórico español}

En nuestro constitucionalismo histórico, la doctrina mayoritaria, siguiendo la habitual división de los textos en conservadores y progresistas, no duda en alinear:

1) entre los aquéllos, a los de 1834, 1845 y 1876, los dos últimos calificados como liberal-doctrinarios, y respecto del primero, aunque no tiene parte dogmática, se extrae de sus preceptos orgánicos la misma consideración o aún más conservadora;

2) entre los progresistas, a las Constituciones de 1812, 1837, 1869 y 1931 más la nonata de 1856.

50 Como hizo la Constitución revolucionaria de 1791, pero sin confundir tan groseramente los conceptos, o sin manipularlos. 
Esta clasificación no nace de la proclamación de la soberanía nacional por parte de los textos señalados en primer lugar y de la soberanía popular de los incluidos en el segundo grupo, sino de la proclamación de aquélla por los textos progresistas y del silencio de los conservadores, seguido de una regulación que evidenciaba otra opción: la de la soberanía interna, que se plasmaba en la denominada Constitución histórica y que, en definitiva, hacía residir la soberanía en el Rey y las Cortes, todo ello con claras raíces en el pactismo feudal Rey-Reino mencionado al comienzo de este trabajo.

Tal clasificación, correcta en líneas generales, no da suficiente cuenta de dos escollos no del todo intrascendentes:

a) La dicción literal de las Constituciones denominadas progresistas concerniente al problema que nos ocupa no coincide. Así, las de 1812 y 1869 proclaman la soberanía nacional; la de 1837 alude a ella en su texto promulgatorio, que, por tanto, no tiene carácter dispositivo; y la de 1931, siguiendo una corriente de pensamiento de entreguerras, proclama la soberanía de España, con lo cual parece no querer comprometer su alineamiento respecto del titular del poder supremo en el Estado, dado que únicamente se pronuncia sobre algo innecesario: el poder independiente del Estado español en el concierto internacional. Estamos, pues, obligados a atender a otros indicadores.

b) Pero esos otros indicadores, al menos algunos, tampoco coinciden. Así, verbigracia, los textos considerados progresistas difieren en la participación del Rey en el poder legislativo (no es el caso del de 1931), o en el tipo de sufragio (universal masculino en el de 1812 y en el de 1869 , universal sin ulterior adjetivación en el de 1931 y censitario en el de 1837), o incluso en la amplitud o restricción del régimen de los demás derechos.

c) E, igualmente, entre los denominados textos conservadores, el de 1834 tiene aún un pie en el Antiguo Régimen, el de 1845 es involutivo y el de 1876, aun siendo conservador, albergó una ley Electoral que prescribía el sufragio universal masculino, lo que no hizo el de 1837, calificado como progresista.

Algo falla, pues, en esas mecánicas y reiteradas alineaciones de los textos fundamentales de nuestra poco brillante y menos ejemplar historia constitucional. Lo que nos obliga a buscar nuestro norte de otro modo, un modo que sea, desde luego, menos mecánico y esté menos pendiente de la superficie literal de los textos (que ni siquiera son correctamente leídos) y preste más atención al fondo del problema. 


\subsection{Constitución de 1812}

Uno de los trabajos en que más esforzadamente se defiende la distinción de Pueblo y Nación y sus correspondientes soberanías es el de J. VARELA SUANCES-CARPEGNA en su por lo demás excelente libro La Teoría del Estado en los origenes del constitucionalismo hispánico (Las Cortes de Cádiz). Frente a las posiciones de los diputados realistas y «americanos», los liberales, sin mengua de algunas diferencias entre ellos, lograron llevar al texto constitucional una concepción de la nación, pese a lo dicho en el artículo $1^{\circ}$, como sujeto unitario e indivisible de existencia puramente ideal, esto es, no identificado con las personas que la integran. La prueba parece encontrarse una y otra vez en la diferencia entre españoles y ciudadanos, o entre ciudadanos simples y ciudadanos activos, como prefería decir el diputado Espiga, y la que media entre sus respectivos derechos: los primeros eran titulares de derechos civiles, pero sólo los segundos lo eran también de de derechos políticos. Y de ahí el paso inmediato de reducir la categoría de ciudadanos, o ciudadanos activos, a los propietarios y rentistas, como terminó siendo en todo el Continente ${ }^{51}$.

En realidad, cuando en el citado estudio de J. VARELA como en otros similares pero menos documentados, se intenta construir la fundamentación de dicha tesis no se hace otra cosa que partir de los conceptos previos y diferenciados de Nación y Pueblo, que es precisamente lo que debería ser objeto de demostración $^{52}$. La cita de SIEYÈS y de los liberales franceses revolucionarios ${ }^{53}$ no es concluyente, puesto que éste identificaba nación y pueblo, y el tercer estado, que encarna la nación/pueblo, lo integran todos excepto la nobleza y el clero porque no trabajan ni producen para el común ${ }^{54}$; y otro tanto puede decirse, según hemos podido apreciar, de los textos constitucionales revolucionarios ${ }^{55}$.

51 VARELA SUANCES-CARPEGNA, J.: La Teoría del Estado en los orígenes del constitucionalismo hispánico (Las Cortes de Cádiz), Centro de Estudios Constitucionales, Madrid, 1983, págs. $245-$ 274.

52 Un muestrario de dichos, usos, frases y textos de periódicos, discursos, etcétera, en GARCÍA TROBAT, P.: Constitución de 1812 y educación política, Cortes Generales, Madrid, 2010, págs. 80-89, del cual tampoco se extrae conclusión alguna acerca de la diferenciación de conceptos de nación y pueblo que nos ha legado CARRÉ DE MALBERG y sus discípulos y ha sido asumida como canónica.

53 VARELA SUANCES-CARPEGNA, J.: «Nación, representación y articulación territorial del Estado en las Cortes de Cádiz», Política y Constitución en España (1808-1978), Centro de Estudios Políticos y Constitucionales, Madrid, 2007, págs. 198-199.

54 Cfr. MÁIZ, R.: Nación y revolución: La teoría política de Enmanuel Sieyès, Tecnos, Madrid, 2007, passim.

55 En un trabajo posterior «El pueblo en el pensamiento constitucional español: 1808-1845», igualmente inserto en Política y Constitución en España, ob. cit., págs. 452-455, J. VARELA se hace eco de la crítica de G. BACOT a CARRÉ DE MALBERG en el sentido de que la distinción entre nación 
Ciertamente, la teoría diferenciadora entre pueblo y nación y sus respectivas soberanías no es sino una interpretación de CARRÉ DE MALBERG, inteligentemente argumentada pero no concluyente, que ha sido asumida como canónica tan unánime como indebidamente ${ }^{56}$.

\subsubsection{La soberanía}

No existe opinión unánime sobre la pretensión de las Juntas provinciales adoptando el apelativo de supremas. Según M. ARTOLA, «[E]l resultado más importante que se deriva de los sucesos de mayo-junio es la traslación del poder a manos de instituciones surgidas del levantamiento popular, fenómeno al que acompaña el sentimiento generalizado de una reasunción popular de la soberanía, sentimiento que se refleja en todos los escritos del momento y que habría de tener una indudable repercusión en el inmediato planteamiento de la organización política» ${ }^{57}$. R. CARR abunda en dicha opinión: durante los primeros meses, las juntas provinciales actuaron como Estados soberanos independientes, enviando embajadas a Londres «de nación a nación». Y añade: «Para los republicanos federales posteriores, la España de la Guerra de Independencia había sido ya una república federal gobernada por los conservadores $»^{58}$. En cambio, para otros autores, como A. MARTIÍNEZ DE VELASCO, el fenómeno sólo consistió en la asunción de una autoridad que había quedado vacía ${ }^{59}$.

y pueblo no arranca de la Revolución, sino que se hizo a partir de 1830, lo que es una importante rectificación, no obstante lo cual insiste en que «los liberales doceañistas evitaron siempre el uso sinonímico de ambos vocablos y atribuyeron la soberanía a la nación, no al pueblo». En cuyo caso éstos serían los «inventores» o creadores de dicha distinción, tesis hasta ahora inédita e históricamente insostenible.

56 CARRÉ DE MALBERG, R.: Teoría General del Estado, cito por la edic. cast. de Universidad Autónoma de México y Fondo de Cultura Económica, México, 1998, págs. 872-1076. Esta hábil y paciente interpretación lleva a su autor a identificar la soberanía nacional con la soberanía del Estado, conclusión que es o una obviedad tautológica o algo más preocupante. Es una obviedad tautológica porque equivaldría a decir que en el Estado el soberano es el Estado. En efecto, una cosa es que, llevada la cuestión al ámbito internacional (interestatal), cada Estado sea reconocido como soberano por los demás independientemente del régimen que encarnen, y otra muy diferente es la que nos ofrece su referencia al ámbito interno, en el cual dicha tautología viene a equivaler a privar a la soberanía nacional, que es un principio de legitimidad democrática, de toda consecuencia jurídico-política, por cuanto la soberanía del Estado es cohonestable con cualquier forma política, sea democrática o autocrática. Me referiré más por extenso a este importante escollo en un próximo libro, La apuesta de Cádiz: democracia representativa y monarquía moderada.

57 ARTOLA, M.: La burguesía revolucionaria, (1808-1874), Alfaguara, Madrid, 1974, pág. 14.

58 CAR, R.: España, 1808-1839, Ariel, Barcelona, 1970, pág. 100.

59 MARTÍNEZ DE VELASCO, A.: «España. 1808-1833», en la obra firmada por él mismo, R. SÁNCHEZ MANTERO y F. MONTERO Manual de Historia de España. 5. Siglo XIX, Historia 16, Madrid, 1990, págs. 54-56. 
El caso es que fue polémica - y no carece de interés teórico-político- la relación entre las Juntas provinciales y la Central. Las primeras daban por sentado que estaban ligadas a su electorado mediante una representación libre, no sometida a más instrucciones que la muy general de organizar la guerra contra Napoleón. Es decir, abandonaron el modelo de mandato imperativo, propio de la sociedad estamental, y dieron el paso hacia el mandato representativo, que habría de ser el usual en el Estado constitucional.

En cambio, pretendieron sujetar ellas a la Junta Central mediante representación vinculada, esto es, mediante mandato imperativo. Como indica M. ARTOLA, esto significaba que las Juntas provinciales ${ }^{60}$ asumían la representación de la nación, en tanto que la Central sería una mera delegación de aquéllas, con poderes limitados y sometida a instrucciones. No obstante, la mayoría de las Juntas provinciales terminaron otorgando a sus diputados poderes muy amplios, y las que los sujetaban a limitaciones les dieron poderes nuevos para que actuaran en libertad y como creyesen en conciencia.

De esta manera, la pluralidad de autoridades locales dio paso a una autoridad nacional unitaria y soberana ${ }^{61}$, que incluso asumió el título de Majestad. Como dice el citado autor, se trataba de una institución irreductible a cualquier otra de las conocidas en España ${ }^{62}$. En su propio seno hubo conciencia de esta su singular naturaleza. Así, la Junta de Sevilla decía:

«Aunque la Constitución española es en sí y debe ser en adelante monárquica, la forma del actual Gobierno no es absolutamente republicana...»,

Y añadía que las Juntas provinciales y la Suprema «forman una República que tiene en depósito la Monarquía».

Pues bien, aunque, como dice J. A. GONZÁLEZ CASANOVA ${ }^{63}$, los debates constituyentes de Cádiz «fueron un curso intensivo sobre la noción de soberanía», no se aprecia en ellos la utilización segregada, y menos aún opuesta, de los términos nación y pueblo, y, por el contrario, hay intervenciones que las emplean como sinónimos. Así, por ejemplo, la del diputado señor Lera, que, para mayor fuerza de nuestro argumento, militaba en las filas conservadoras, identificó

60 ARTOLA, M.: Antiguo Régimen y revolución liberal, Ariel, Barcelona, 1983, págs. 162163; del mismo autor, La burguesía revolucionaria (1808-1874), Ob. cit. pág. 15, y Los orígenes de la España contemporánea, Centro de Estudios Políticos y Constitucionales, Madrid, 2000.

${ }^{61}$ Unas veces se autocalificaba así y otras como representación de la soberanía nacional.

62 ARTOLA, M.: Los orígenes..., ob. y lug. cits.

${ }^{63}$ GONZÁLEZ CASANOVA, J. A.: «La cuestión de la soberanía en la historia del constitucionalismo español», en revista Fundamentos, n 1/1998, monográfico sobre Soberanía y Constitución, Principado de Asturias, 1998, págs. 298-299 
pueblo y nación en el artículo $1^{\circ}$ de la Constitución: «El Pueblo o la Nación española... es la reunión de todos los españoles de ambos hemisferios» ${ }^{64}$.

En cuanto al sujeto titular de la soberanía, Jovellanos (seguido por bastantes diputados por su indudable autoridad: Pérez Villamil, Capmany...) admitía como verdad infalible que la soberanía pertenece originalmente a toda asociación política puesto que los hombres se unen para vivir en sociedad. Pero, una vez constituida ésta, deja de pertenecer al cuerpo social y reside en la persona en que ésta la ha depositado, la cual, si es Rey, la transmite por herencia a sus descendientes.

Por su parte, los conservadores realistas aducían que el pacto Rey-Reino no era una mera hipótesis teórica, sino un pacto realmente histórico. También suscribió tal tesis MARTÍNEZ MARINA ${ }^{65}$.

El enfrentamiento armado de la nación española, sin Rey, a Napoleón significó la asunción de su propio destino, de su propio poder decisorio, de su soberanía. Así, el principio de soberanía nacional brotó del modo más natural: si la mayoría de los diputados estaban de antemano dispuestos a proclamarlo, los hechos vinieron a facilitarles la labor. Bien es verdad que también afirmaban la soberanía de las Cortes Constituyentes, pues éstas, ya en su primera reunión, de 24 de septiembre de 1810, aprobaron un Decreto que decía literalmente:

«Los diputados que componen este Congreso y que representan a la nación española se declaran legítimamente constituidos en Cortes Generales y extraordinarias y que reside en ellas la soberanía nacional».

El problema consiste en interpretar correctamente el término «reside». En su contexto, parece no querer significar la asunción de la titularidad, sino, como indica el propio texto en su inicio, su representación; y así lo diría después el propio texto constitucional. Era, por lo demás, muy difícil negar la soberanía nacional por las razones dichas. Y así, aunque los realistas la negaron la soberanía nacional, como también negaron el poder constituyente por cuanto — decíanel Reino estaba ya constituido y, todo lo más, cabía la reforma de las viejas leyes, la mayoría de los diputados, de ideología liberal, lograron, por el contrario, imponer su criterio, menos restrictivo, acerca del poder constituyente de la nación soberana y su derecho a establecer su forma de gobierno ${ }^{66}$.

${ }^{64}$ Intervención del diputado señor Lera, DSCG de 28 de agosto de 1811.

${ }^{65}$ MARTÍNEZ MARINA, F: Teoría de las Cortes, Clásicos del Pensamiento Político Asturiano, Principado de Asturias, 1996, tomo I, págs. 52-53.

${ }^{66}$ Ibidem, lug. cit. 
El Decreto mencionado fue extremadamente importante para determinar la posición jurídico-política de las Cortes y algunos principios de la futura Constitución. En él se afirmaba, además de la legítima constitución de las Cortes Generales y extraordinarias y la residencia de la soberanía nacional en ellas,

1. la representación nacional de los diputados;

2. la nulidad de la renuncia de Fernando VII a la Corona por haber sido hecha con violencia y sin consentimiento de la nación española;

3. el principio de división de poderes, reservándose las Cortes el legislativo en toda su extensión y habilitando interinamente a la Regencia para el ejercicio del ejecutivo;

4. la garantía de la inviolabilidad parlamentaria.

El texto de 1812 contiene varios preceptos susceptibles de análisis en nuestro trabajo, en los cuales puede detectarse una concepción amplia del titular de la soberanía. Citemos en primer término el artículo $3^{\circ}$, que proclama de modo coherente con la referida y temprana toma de posición de las Cortes:

«La soberanía reside esencialmente en la Nación, y por lo mismo pertenece a ésta exclusivamente el derecho de establecer sus leyes fundamentales».

Este precepto, que es parejo al de la Declaración francesa de 1789 (art. $3^{\circ}$ ) en su alusión a lo esencial de dicha titularidad, lo que significa es que no puede ser de otro modo sin desnaturalizarse tanto la soberanía como la nación. El adverbio «esencialmente» fue añadido a lo aprobado en el decreto de 24 de septiembre de 1810. Como argumentó Muñoz Torrero, significa que esa titularidad esencial de la soberanía es un elemento constitutivo de la nación «en calidad de Estado libre e independiente»; y, por tanto, no puede ser despojada de ella.

El diputado señor Alcocer abogó por suprimir el adverbio «esencialmente» o sustituirlo por «originalmente» o por «radicalmente», a lo que respondió el Conde de Toreno que estos otros dos adverbios aludían al origen, inherente de la Nación, que es lo que significa «esencialmente»; esta titularidad esencial equivale a decir que dicho derecho de soberanía coexistirá siempre con la Nación mientras ésta no sea destruida. La Nación, pues, no puede desprenderse de su soberanía, como el hombre no puede desprenderse de sus facultades físicas ${ }^{67}$.

Esta cuestión, sin embargo, era menor, no sólo porque las expresiones de originalidad y radicalidad pueden ser interpretadas como más exigentes de lo que dijo el Conde de Toreno en su respuesta, y así lo prueba su empleo en no pocos textos constitucionales americanos nada sospechosos de tibieza en el reclamo de

\footnotetext{
${ }^{67}$ Intervención del Conde de Toreno, DSCG de 28 de agosto de 1811.
} 
la soberanía nacional ${ }^{68}$, sino también el hecho de que el Discurso Preliminar utiliza los dos conceptos: la originalidad y la esencialidad ${ }^{69}$ y el propio Argüelles, coautor del Discurso, empleó también el adjetivo «originario» en los debates refiriéndose al poder constituyente de la nación ${ }^{70}$.

Por otra parte, como ha comentado J. VARELA, la concepción de la nación de los diputados liberales de Cádiz, que difería en tantos puntos de la sustentada por los diputados realistas y «americanos», también lo hacía en el sustrato puramente individualista que le atribuían frente al concepto organicista y corporativo (estamental o territorial, o ambas cosas a la vez) de éstos ${ }^{71}$.

\subsubsection{La nación como Estado}

El diputado conservador señor Lera adujo que el artículo no debía entrar en la Constitución porque se trataba de una cuestión teórica, opinable y que trajo fatales consecuencias en Francia. Además, la cuestión de la soberanía era de Derecho público universal, puesto que hace referencia a las relaciones internacionales, y ningún Estado puede regularla por sí solo ${ }^{72}$.

Estas palabras pueden ser entendidas como derivadas del concepto de nación como unión o reunión de individuos de un país, o de la nación como Estado. Y esto es algo que, además de evidente de suyo, no dejó de subrayar Argüelles, el cual identificaba la «soberana voluntad» de la Nación con su independencia respecto de otras naciones ${ }^{73}$. Como también se aprecia en la intervención del conde de Toreno en defensa de la soberanía nacional, en la que, después de estimarla como la soberanía de los españoles y llamar usurpador a Napoleón, dijo: «Un Estado se llama libre cuando es dueño de sí mismo y tiene el derecho de hacer sus propias leyes $»^{74}$, que es justamente lo que el artículo $3^{\circ}$ dice de la nación, a saber: que a la nación pertenece exclusivamente el derecho de establecer sus leyes fundamentales.

68 Así, por ejemplo, las Constituciones de Maryland, Nueva York, Nueva Hampshire y Vermont, como también la Declaración de Derechos de Carolina del Norte.

69 «¿Quién... podrá resistirse todavía a reconocer como principio innegable que la autoridad soberana está originaria y esencialmente radicada en la Nación?»

70 TOMÁS Y VALIENTE, F.: «Agustín de Argüelles en Cádiz», OC, Centro de Estudios Constitucionales, Madrid, 1997, t. II, pág. 4596.

71 VARELA SUANCES-CARPEGNA, J.: La Teoría del Estado en los orígenes del constitucionalismo bispánico (Las Cortes de Cádiz), ob. cit., pág. 262.

72 Intervención del diputado señor Lera, DSCG de 28 de agosto de 1811.

73 TOMÁS Y VALIENTE, F.: «Agustín de Argüelles en Cádiz», ob. cit., pág. 4594.

${ }^{74}$ Intervención del Conde de Toreno, DSCG de 29 de agosto de 1811 (con ortografía actual). 
No tener presente esta doble acepción del término nación, como reunión de todos sus miembros personales y como Estado, es origen de no pocos equívocos a la hora de interpretar los textos del primer constitucionalismo.

Y todavía cabría interpretar el concepto constitucional de nación española como equivalente a España. Pues bien, junto a este concepto de nación, que es ciertamente válido y nada sospechoso de escasamente democrático, el artículo primero de la Constitución, precisamente el primero, la declara integrada por «todos los españoles de ambos hemisferios». Mediante un simple silogismo en bárbara, se deduce que la titularidad de la soberanía recae en todos los españoles ${ }^{75}$.

En un sentido convergente con el anterior, el artículo $2^{\circ}$ sale al paso de una posible interpretación de la Nación como ente abstracto susceptible de su personificación por la Corona o por la Dinastía reinante ni tan correcto como un simple pedazo de tierra susceptible de apropiación privada: «La Nación española es libre e independiente, y no es ni puede ser patrimonio de ninguna familia ni persona».

La nación puede ser entendida en el texto citado bien como suma de personas de un país, bien como ese mismo país, bien como ese país políticamente organizado, esto es, un Estado. Eran ideas de la más avanzada cultura ambiente. Diecisiete años antes KANT había publicado su breve ensayo La paz perpetua, en una de cuyas primeras páginas puede leerse:

$2^{\circ}$. Ningún Estado independiente — grande o pequeño, lo mismo da— podrá ser adquirido por otro mediante herencia, permuta, compra o donación. Un Estado... es una sociedad de hombres sobre la cual nadie, sino ella misma, puede mandar o disponer $»^{76}$.

En consecuencia, se refiera el precepto constitucional a Estado o a nación, tiene hondo significado lo dicho: tanto la unión de españoles, como España y como el Estado español son libres e independientes y no son ni pueden ser patrimonio de ninguna familia ni persona. Con lo que, de paso, está señalando elegantemente, pero de forma nada críptica, el atropello constitucional protagonizado por los dos Borbón, padre e hijo, que dio como resultado la cesión de la Corona española al emperador Bonaparte y de éste a su hermano José.

75 La aparente indistinción entre los españoles «europeos» y los de Ultramar no debe llevarnos a pensar en una integración jurídica de los grupos indígenas, como tampoco lo fueron otros pueblos indígenas de otras latitudes. Sencillamente, aún no se había abolido la esclavitud.

${ }^{76}$ KANT: La paz perpetua, ediciones castellanas de Tecnos, Madrid, 1985, pág. 6; y $4^{\mathrm{a}}$ de Espasa Calpe (junto a Lo bello y lo sublime), Madrid, 1964, pág. 92. De cada una he tomado una frase en atención a su mejor castellano. 
Una intervención del conde de Toreno es muy elocuente sobre esta cuestión:

«Napoleón, suponiendo que todos los derechos de la Nación pertenecían única y privativamente a la familia Real, obligó a ésta a renunciarlos, y en virtud de este hecho pretende haber adquirido un derecho legítimo a darnos una Constitución y a establecer el Gobierno de España, sin contar para nada con la voluntad general». Por eso dice a continuación: «El artículo de que se trata, reducido a su expresión más sencilla, no contiene otra cosa sino que Napoleón es un usurpador de nuestros más legítimos derechos; que ni tiene ni puede tener derecho alguno para obligarnos a admitir la Constitución de Bayona, ni a reconocer el Gobierno de su hermano... Un Estado se llama libre cuando es dueño de sí mismo y tiene el derecho de hacer sus propias leyes ${ }^{77}$.

El mismo Fernando VII nos brinda un argumento sobre el desolador episodio de Bayona, que los constituyentes gaditanos tuvieron buen cuidado de utilizar para reafirmar la legitimidad de su posición. En efecto, se opuso a la devolución de la Corona a su progenitor diciendo que eso no podía hacerse sin «el expreso consentimiento de la nación española reunida en Cortes y en un lugar seguro...» Ahora bien, comoquiera que Napoleón le exigió la cesión en términos nada jurídicos ( Príncipe, es necesario optar entre la cesión y la muerte...»), Fernando VII se avino al día siguiente ${ }^{78}$.

Otro ribete del problema consiste en que también la propia Constitución, como norma suprema, es depositaria de la soberanía nacional. Por eso el Rey lo es ya «por la gracia de Dios y de la Constitución» (art. 173), y queda obligado a guardarla y hacerla guardar, pues tanto las Cortes como el Rey son ahora poderes constituidos ${ }^{79}$, si bien, como hemos reiterado, las Cortes tenían poderes superiores, principalmente su preeminencia sobre el Rey en la potestad legislativa y su potestad constituyente constituida en exclusiva, amén de una importante intervención en asuntos de la Corona.

Para finalizar este análisis, aduciremos dos nuevas ideas de la propia Constitución y en las que nos detendremos más adelante:

a) Como derivación de su soberanía, el mismo artículo $3^{\circ}$ reconoce a la Nación española la titularidad del poder constituyente, esto es, el de darse a sí misma sus leyes fundamentales.

b) Las Cortes son la reunión de todos los diputados, los cuales representan a la nación (art. 27), afirmación que, igual que la de la soberanía na-

77 Intervención del Conde de Toreno, DSCG de 29 de agosto de 1811 (transcrito con ortografía actual).

78 Cfr. MARTínEZ DE VELASCO, A.: «España. 1808-1833» págs. 41-43.

79 Véase más adelante una somera alusión al poder constituyente constituido de las Cortes. 
cional, se reitera en muchos otros preceptos constitucionales en los que se vuelve a hablar de representación nacional, representación de la nación, de toda la nación, etcétera, disponiendo además que así se haga constar en los poderes amplios que, conforme a los artículos 99 y 100, los electores provinciales deben otorgar a los diputados electos.

Como consecuencia de este novedoso y complejo planteamiento, la Monarquía dejaba de ser una forma de Estado, en el sentido bodiniano de la expresión, para ser una forma de gobierno, y el Rey, que no participó en el poder constituyente originario, quedaba también excluido del poder constituyente constituido o poder de reforma constitucional ${ }^{80}$.

Y aunque Fernando VII, en 1814, rechazó el principio que estamos estudiando por considerarlo una usurpación de su regia soberanía, es lo cierto que, como hemos indicado unas líneas más atrás, las Cortes se habían apoyado en él varios años antes, en el ya citado Decreto de 24 de septiembre de 1810 , precisamente para reivindicar la legitimidad del Deseado a pesar de las abdicaciones de Bayona:

«Las Cortes... reconocen, proclaman y juran de nuevo por su único y legítimo rey al señor don Fernando VII de Borbón y declaran nula... la cesión de la Corona, que se dice hecha en favor de Napoleón no sólo por la violencia que intervino en aquellos actos injustos e ilegales, sino principalmente por faltarle el consentimiento de la nación» (cursiva mía).

Así, pues, nos hemos encontrado de pronto con conceptos y realidades nuevos en España: soberanía nacional, Cortes representativas de la nación y, consecuentemente, ejercicio parlamentario de esa soberanía nacional y del poder constituyente constituido.

Aparentemente, al menos, nación española es sinónimo de pueblo español, y soberanía nacional lo es de soberanía popular, contra lo que suele decirse. En todo caso, serán quienes lo nieguen los que hayan de desmontar los argumentos expuestos.

Esa soberanía, decía el conde de Toreno en sede constituyente y en polémica con Borrull, Aner y Terreros, era indivisible e inalienable ${ }^{81}$, al modo de las Constituciones revolucionarias francesas, lo que una vez más puede estimarse como referido a la nación-pueblo y a la nación-Estado.

${ }^{80}$ GONZÁLEZ CASANOVA, J. A.: «La cuestión de la soberanía en la historia del constitucionalismo español», ob. cit., págs. 298-300.

${ }^{81}$ Intervención del diputado conde de Toreno, DSCG de 28 de agosto de 1811. 


\section{LA CIUDADANÍA EN CÁDIZ}

La cuestión de la ciudadanía es crucial en nuestro estudio. De la respuesta que obtengamos tras su análisis depende el resultado final acerca del carácter de la soberanía nacional enunciado por el texto constitucional.

\subsection{El derecho de ciudadanía}

Hecha en Cádiz la opción por el monocameralismo ${ }^{82}$, el constituyente idea un complicado sistema electoral que trataba de conciliar dicha opción con el respeto al principio de representación nacional. Lo que debemos hacer, por tanto, es comprobar si los requisitos impuestos para el ejercicio del derecho de ciudadanía son jurídicamente adecuados o no.

Y sucede que, al iniciar esta comprobación cabría detectar en nuestra primera Constitución una contradicción entre los primeros artículos arriba examinados y la regulación del sistema electoral, con el correspondiente derecho de participación política. A esta primera impresión nos lleva la conclusión del silogismo formulado en el subepígrafe anterior acerca de que la soberanía reside en todos los españoles. Ahora bien, el derecho de participación política es un derivado inmediato de la soberanía; más aún, es un elemento esencial de la misma. Luego, continuando con el silogismo, que ya es un «sorites», todos los españoles deberian ser titulares de este derecho.

Veamos el resto de la regulación constitucional de la materia:

1. El artículo 27 inicia la regulación de un proceso electoral en cuatro fases y determina que «los diputados... son nombrados por los ciudadanos en la forma que se dirá».

2. El proceso comienza en las Juntas electorales de parroquia, que, conforme al artículo 35, se componen de «todos los ciudadanos avecindados y residentes en el territorio de la parroquia respectiva», incluidos los eclesiásticos seculares. En esta fase se nombran (se eligen) a los electores parroquiales (art. 38).

3. Otros preceptos regulan las fases siguientes, en las cuales son electores los elegidos en la anterior.

4. En cuanto al derecho de sufragio pasivo, para ser elector parroquial sólo se necesita, según el artículo 45, además de los requisitos para formar parte de la Junta de parroquia, ser mayor de 25 años. Pero, más adelante, el artículo 91 dispone, para ser diputado de Cortes, requisitos más exigentes de

${ }^{82}$ Cfr. BERTELSEN, R.: El Senado en España, Instituto de Estudios Administrativos, Madrid, 1974. 
nacimiento o vecindad en la provincia en cuestión y excluye a los eclesiásticos regulares. Y el artículo siguiente requiere, además, «tener una renta proporcionada, procedente de bienes propios».

\subsection{Españoles y ciudadanos}

Reparemos en que, en vez de hablar de españoles, el sujeto de los derechos de ciudadanía son los ciudadanos. Por tanto, para poder asegurar que este sufragio activo era universal (masculino) hemos de despejar la incógnita de quiénes eran ciudadanos y cuál es la relación existente entre estas dos categorías: españoles y ciudadanos.

A juicio de M. MEDINA ORTEGA, la Constitución de Cádiz mantiene elementos del Derecho español histórico en el concepto que adopta de «españoles» y, en cambio, su regulación de la ciudadanía rompe con el mismo y se alinea con principios de la Revolución francesa considerando la ciudadanía «como vínculo fundamental entre el individuo y la comunidad política» ${ }^{83}$. Parece, pues, que hay diferencias.

Un constituyente tan destacado como Argüelles dijo en sede constituyente:

«Después del Decreto de señoríos, las leyes ya no pueden menos de ser iguales para todos los españoles; ¿por qué, pues, todos los ciudadanos no han de tenerla parte que les corresponde en su formación?» ${ }^{84}$

La frase es digna de comentario. En primer lugar, Argüelles defiende la igualdad de todos los españoles. Pero, en segundo término, apelando aparentemente al mismo principio, aboga por que la titularidad del derecho de sufragio corresponda únicamente a los ciudadanos. Pero vayamos al texto constitucional:

El título III, capítulos I a III, que regulan el modo de formarse las Cortes, incluido el sistema electoral, reduce tal participación a los ciudadanos. Esta distinción venía en cierto modo presagiada por el artículo 23, que reserva a los ciudadanos el derecho a obtener empleos municipales y el de elegir para ellos en los casos señalados por la ley. Cabía esperar entonces que, si esa reserva se hacía para los empleos municipales, no otra cosa habría de suceder con el cargo de diputado, mucho más importante, como así resultó ser.

No habría contradicción si todos los españoles fueran ciudadanos, como establece respecto de los franceses la Constitución jacobina, pero no es así: la Constitución gaditana diferencia entre españoles y ciudadanos españoles, siendo

${ }^{83}$ MEDINA ORTEGA, M.: «Los ciudadanos españoles en el texto constitucional», en ESCUDERO, J. A. (dir.): Cortes y Constitución de Cádiz, 200 años, Espasa, Madrid, 2011, vol. III, pág. 683.

${ }^{84}$ DSCG de 12 de septiembre de 1811. 
esta categoría algo más reducida que aquélla. Así se desprende del capítulo V del título II (arts. 18 a 26). Todavía cabría la coherencia si la reducción numérica de uno a otro colectivo obedeciera a causas democráticamente aceptables. Pero la doctrina no ha sido unánime al respecto.

El propio Argüelles admitió en sede constituyente, bien que a efectos dialécticos, la sinonimia de ciudadano y vecino. Y ojalá, dijo, hubiera podido ser la Comisión tan liberal como lo son sus sentimientos, «pero ha tenido que sacrificarlos a la conveniencia pública, al bien general del Estado».

En cuanto a los españoles procedentes de África, pese a que el decreto de 15 de septiembre de 1810 declaró la igualdad de todos los habitantes de Ultramar, la Constitución introdujo la distinción entre ambas categorías de personas, ciertamente importante porque sólo los ciudadanos eran admitidos al ejercicio de los derechos políticos. El principal problema para la no consideración de todos los españoles como ciudadanos era la existencia legal de la esclavitud, situación en la que se encontraban muchos españoles negros de origen africano, los indios puros y las denominadas «castas», es decir, mestizos y mulatos.

El problema de la esclavitud suscitó un largo e intenso debate en sede constituyente, en la que hubo no pocas intervenciones abolicionistas, principalmente de diputados de Ultramar ${ }^{85}$. Tampoco es de extrañar. Ya hacía años que determinados pensadores, como CONDORCET, la ponían en cuestión con argumentos incontestables ${ }^{86}$. Pero las ideas contracorriente tardan en madurar y en permear las conciencias, y más aún los Ordenamientos jurídicos.

Sin duda, hay en la regulación constitucional un elemento racista, como destaca MEDINA ORTEGA ${ }^{87}$, pero, estando como estaba reconocida la esclavitud en los Ordenamientos jurídicos europeos respecto de las poblaciones de los demás continentes en los que eran soberanos sin que fuera realmente abolida hasta finales de siglo XIX, la acusación se relativiza al juzgarla en el contexto de la cultura de la época. Mal se le puede reprochar a nuestra primera Constitución que no se adelantara al mundo para ser pionera en tal cometido.

La exclusión de los españoles originarios de África y de las «castas» también era una forma de asegurar la mayoría parlamentaria a los diputados metropoli-

${ }^{85}$ Cfr. MEDINA ORTEGA, M.: «Los ciudadanos españoles...», ob. cit., págs. 680-681, y MIRALLES SANGRO, P.-P.: «Españoles y extrangeros en la Constitución de Cádiz», en la misma obra y tomo, págs. 633-634.

86 CONDORCET: Reflexiones sobre la esclavitud de los negros, cito por la edición Oeuvres Complétes, Henrich, Fuchs, Köening et Levrault, Schöell et Cie, París 1804 (año XIII), vol. XII, págs. 93-94, 105 y 162-166, entre otros pasajes.

87 MEDINA ORTEGA, M.: «Los ciudadanos españoles...», ob. cit., págs. 676 y 681-682. 
tianos. No obstante, es cierto que tal regulación pudo echar al mestizaje español en manos del independentismo ${ }^{88}$.

\subsection{La condición de ciudadano, jurídicamente abierta}

Argüelles confiesa que el asunto entrañaba muchos escollos: «Scila y Caribdis amenazaban a ambos lados». Haciendo viva expresión de que aprobar el artículo le producía violencia a sus sentimientos y a su genio, entendía que lo más prudente era, en vez de admitir a los derechos de ciudadanía a una numerosa clase de españoles que no se halla en disposición de desempeñarlos, «proporcionar el medio [de] que progresiva y gradualmente pueda ir adquiriendo su goce». Serían las Cortes sucesivas, con más tranquilidad y con más luces en tan delicado punto, las que pudieran hacer esa extensión de derechos de ciudadanía, porque los términos del artículo lo permitían ${ }^{89}$ dado que efectivamente la condición de ciudadano no era una categoría cerrada.

En efecto, tal condición podía ser adquirida por los extranjeros, por los libertos y por esa población de origen africano, en determinadas condiciones en cada caso; como también podía perderse o ser suspendido el ejercicio de los derechos correspondientes. Abordamos a continuación este segundo aspecto.

Dispone el artículo 24 los supuestos de pérdida de la calidad de ciudadano y, por tanto del derecho de participación, alguna de las cuales (por ejemplo, la tercera: «Por sentencia en que se impongan penas aflictivas o infamantes, si no se obtiene rehabilitación») merecería un estudio por sí sola. Y el precepto subsiguiente hace lo propio con los casos de suspensión de la ciudadanía, que son los siguientes: 1) el incapaz físico o moral ${ }^{90}$, así decidido por resolución judicial; 2) el deudor quebrado y el deudor a los caudales públicos; 3) el sirviente doméstico; 4) quien no tuviere empleo, oficio o modo de vivir conocido; 5) el procesado criminalmente; 6) el analfabeto.

Todas estas exclusiones son sumamente discutibles, incluso rechazables (unas más que otras), desde categorías actuales, pero eran habituales en los escritos y en los ordenamientos jurídicos de la Europa ilustrada, como veremos en el apartado siguiente. La razón esgrimida era que el voto debe ser independiente para que el Parlamento lo sea, y éste debe serlo para encarnar verdaderamente

88 Ibidem, pag. 682.

89 Intervención del diputado señor Argüelles en el debate sobre el artículo 22, DSCG de 4 a 7 y 10 de septiembre de 1811.

90 Léase psíquico. Esta acepción del adjetivo «moral», técnicamente impreciso, tiene reflejo en la Constitución española vigente, cuyo artículo 15.2 habla de integridad moral. 
la representación de la nación; y se entendía comúnmente que los individuos incursos en el supuesto tercero no eran independientes; los incapaces psíquicos no comprendían el significado del acto de la elección, los analfabetos no discernían suficientemente entre las opciones que se le presentaran y los demás no merecían el disfrute del derecho por sus deudas, por su situación procesal o por ser considerados vagos o maleantes. Incluso era frecuente defender la exclusión de los eclesiásticos regulares del derecho de sufragio por estimarse que su voto de obediencia les impedía un ejercicio libre del mismo.

Distinto es el carácter de la exclusividad masculina en la titularidad del derecho de sufragio, así como la persistencia de la esclavitud, que excluía del derecho de sufragio (y aun de otros derechos) a una enorme cantidad de personas de origen africano que trabajaba en estas provincias.

En fin, pese a lo dicho en el artículo 28 ( «La base para la representación nacional es la misma en ambos hemisferios»), tampoco los ciudadanos de Ultramar eran tratados electoralmente en condiciones de igualdad respecto de los de la metrópoli, puesto que estaban infrarrepresentados respecto de lo que en pura proporción les hubiera correspondido.

\subsection{Alguna comparación para evitar el anacronismo}

De las causas de incapacidad para el ejercicio del derecho de sufragio, llama la atención la terminología empleada, propia de la época pero actualmente en desuso por su escasa sensibilidad y no tanto por su fondo, puesto que también actualmente existen penas que comportan la accesoria de pérdida de los derechos políticos.

Hoy en día tampoco es ciudadano todo habitante del país o, al menos, no todos son admitidos al derecho de sufragio, existiendo causas de suspensión de los derechos políticos, algunas coincidentes con las antes enunciadas. Son cláusulas de seguridad del Ordenamiento frente a quienes — con razón o sin ella— juzga indeseables o no merecedores del mismo. Pero, en realidad, son prácticamente las mismas que pueden encontrarse en ¿Qué es el Tercer estado? y en la Constitución de1791, como exponemos a continuación:

En efecto, en la obra de referencia de SIEYÈS, podemos leer:

«No puede haber, en ningún género, una libertad o un derecho sin límites... Así, por ejemplo, la ley debe determinar la edad por debajo de la cual se será inhábil para representar a sus conciudadanos. Así, las mujeres... Es constante que un vagabundo o un mendigo no puedan ser encargados de la confianza política de los pueblos. Un doméstico y todo lo que está bajo la dependencia de un amo, un ex- 
tranjero no naturalizado, ¿serían admitidos a figurar como representantes de la nación?» ${ }^{91}$

Por lo que se refiere a la Constitución de 1791, la regulación de la ciudadanía presenta diversas variantes:

a) La regulación de la condición de ciudadano francés no es nada restricti$\mathrm{va}^{92}$

b) Pero se puede perder por las siguientes causas:

1. Por la naturalización en un país extranjero.

2. Por la condena a penas que comporten la degradación cívica, mientras no se haya rehabilitado.

3. Por una sentencia en rebeldía, mientras no sea anulada.

4. Por la afiliación a cualquier orden de caballería o corporación extranjera que pudiera implicar pruebas de nobleza o distinciones de nacimiento o que pudiera exigir votos religiosos.

c) La regulación de la ciudadanía activa es mucho más limitada, incluyendo el elemento económico censitario ${ }^{93}$. Se exigía:

1. Ser francés por nacimiento o por naturalización.

2. Tener cumplidos veinticinco años.

3. Estar domiciliado en la ciudad o en el cantón durante el tiempo que determine la ley.

4. Pagar una contribución directa igual, al menos, al valor de tres jornales, y presentar recibo.

5. Estar inscrito en el municipio de su domicilio en la lista de la guardia nacional.

6. Haber prestado el juramento cívico.

d) Pero no eran ciudadanos activos o estaban excluidos del ejercicio del derecho de ciudadanía activa ${ }^{94}$ :

1. Los servidores domésticos a sueldo.

2. Los que se encontraran bajo acusación.

3. Los declarados en quiebra o insolventes con pruebas auténticas y no aporten un recibo de descargo general de sus acreedores.

A su vez, el Proyecto de Constitución girondina cifra las causas de pérdida de la condición de ciudadano la demencia judicialmente comprobada y la condena

91 SIEYÈS: ¿Qué es el Tercer estado?, ob. y edic. cit., pág. 32.

92 Artículos $2^{\circ}$ a $4^{\circ}$ del título II.

93 Artículo $2^{\circ}$ de la sección II del capítulo I del título III.

94 Artículos $2^{\circ}$ y $5^{\circ}$ de la sección II del capítulo I del título III. 
a penas «que comportan la degradación cívica»; y así mismo el artículo $6^{\circ}$ dispone las causas de pérdida de la nacionalidad francesa (arts. $5^{\circ}, 6^{\circ}$ y $7^{\circ}$ ).

Como se puede apreciar, nuestra primera Constitución bien pudo inspirarse en estos precedentes, pero resultó ser menos restrictiva que la de 1791 y, desde luego, nada censitaria, como tampoco lo era la girondina.

Por otra parte, la esclavitud existía al menos en las posesiones extrametropolitanas que tenían los países europeos y, con la excepción más formal que real de Estados Unidos, no se llegó a abolir hasta finales del siglo XIX y donde se había abolido antes, no se cumplía el mandato legal. Respecto de la exclusividad del varón en la titularidad del derecho de sufragio, es algo que no merece ser explicado de puro obvio: su discriminación no se producía sólo referida a los derechos políticos, sino que era general y afectaba a todo el Ordenamiento jurídico; existía tanto en toda Europa como en Estados Unidos y obedecía a razones muy conocidas y estudiadas en una amplísima literatura, a la que remito, no sin antes resaltar el anacronismo que significa reprocharle a la Constitución de 1812 que no derribara un tabú que se ha extendido hasta bien entrado el siglo XX.

La infrarrepresentación de los ciudadanos de las provincias de Ultramar no era tampoco nada que no existiera entonces en todos los territorios sometidos a la soberanía de una metrópoli europea, y hoy sigue en los propios Estados demoliberales como producto de los hábiles manejos de las legislaciones electorales, incluida la española vigente, conforme a la cual la población de la mitad de las provincias está sobrerrepresentada a costa de la de otras, que se encuentra claramente infrarrepresentada. ¿Acaso es sensato pedirle mayor exquisitez representativa a una Constitución primeriza de hace dos siglos?

Por lo demás, la Constitución gaditana desplaza temporalmente la exclusión de los analfabetos hasta 1830, confiando en la erradicación del analfabetismo. Por esta vía si habría podido llegarse a una forma de sufragio capacitario, pero es evidente que lavotuntas constituentis era la contraria: llegar en dos décadas a al igualdad de los españoles también en instrucción pública.

\subsection{Conclusión: el controvertido sufragio "gaditano»}

No es de extrañar, por consiguiente, que el tipo de sufragio adoptado por el constituyente gaditano haya suscitado interpretaciones diversas. Algunos autores hablan de sufragio censitario, como es el caso de B. CLAVERO y J. TOMÁS VILLARROYA, que no consideran que el sufragio fuera universal porque se esta- 
blecían determinados requisitos y exclusiones, o bien porque se restringía considerablemente en las sucesivas fases ${ }^{95}$. En cambio, F. FERNÁNDEZ SEGADO se inclina por considerar como universal el sufragio activo en la fase inicial de las elecciones ${ }^{96}$; y P. J. GONZÁLEZ-TREVIJANO lo califica como sufragio con proyección moderadamente universal ${ }^{97}$. Yo también he escrito que el sufragio era universal ${ }^{98}$. Todas estas afirmaciones, de uno y otro signo, son susceptibles de matices, que es lo que a continuación intentamos hacer.

El sufragio pasivo para optar a un acta de diputado no admite duda: estaba concebido por el constituyente como propiamente censitario, puesto que a los requisitos exigidos para ser elector de partido se añadía, además de ser natural de la provincia o tener una residencia en ella de, al menos, siete años, disponer de una renta anual «proporcionada» (sic), procedente de bienes propios. Con todo, este último requisito quedaba en suspenso hasta que unas Cortes ulteriores decidiesen llevarlo a efecto (arts. 91-93), lo cual no llegó a ocurrir nunca. Por lo demás, como no había candidaturas, los diputados electos se podían encontrar con un acta que los acreditaba como tales sin que hubieran hecho ninguna intención de serlo. Y no podían renunciar al cargo.

La duda y la polémica se circunscribe al sufragio activo. Por eso, antes de concluir de un modo u otro, debemos hacer una precisión: dichas elecciones habían de desarrollarse a lo largo de cuatro fases ${ }^{99}$ en Juntas de parroquia, de partido (judicial) y de provincia, de manera que los elegidos en cada fase eran los electores en la siguiente. Por eso, debemos distinguir entre el elector del primer paso del proceso electoral, que se celebraba en las parroquias, y el elector parroquial, que era elegido en la segunda fase para, a su vez, ser elector en la tercera.

Ya los primeros electores, los de la primera fase en las Juntas electorales de Parroquia, habían de ser ciudadanos, no bastando, por tanto, la condición de nacional o de español. Pero, si no era universal en el sentido actual de la palabra, tampoco era censitario por cuanto las causas de exclusión no tenían carácter económico. Era todo lo universal que podía ser en la época, recién salidos del ré-

95 Clavero, B.: Manual de Historia constitucional de España, Alianza Universidad Textos, Madrid, 1989, pág. 31. TOMÁS VILLARROYA, J.: Breve historia del constitucionalismo español, Editorial Planeta, Barcelona, 1976, pág. 17.

96 FERNÁNDEZ SEGADO, F.: Constituciones Históricas Españolas, Civitas, Madrid, 1986, págs. 86 y 97.

97 GONZÁlEZ-TREVIJANO, P. J.: «El concepto de nación en la Constitución de Cádiz», en ESCUDERO, J. A. (dir.): Cortes y Constitución de Cádiz..., ob. cit., t. III, pág. 615.

98 TORRES DEL MORAL, A.: «Las Cortes según la Constitución de 1812», en ESCUDERO, J. A. (dir.): Cortes y Constitución de Cádiz..., ob. cit., t. III, págs. 3-16.

99 Seguía en ello a la Constitución francesa de 1791, pero duplicaba su número de votaciones. 
gimen absoluto. Y, como hemos comentado anteriormente, las causas de pérdida y de suspensión de los derechos de ciudadanía eran también los propios de la época y algunos incluso siguen vigentes en la actualidad. Por lo demás, siendo como era la categoría de ciudadano jurídicamente abierta, se comprenderá que calificar con una sola palabra la naturaleza del sufragio «gaditano» se presta al error precisamente por falta de matices.

En fin, siguiendo a M. ARTOLA, podemos advertir de que la apuesta por el mocameralismo significó una apuesta por la burguesía como beneficiaria del sistema frente a la nobleza y al clero que hubieran podido tener sus escaños en una Cámara Alta ${ }^{100}$. A ese resultado también contribuían otros datos del sistema electoral: el carácter censitario del sufragio pasivo, que obligaba a la elección de propietarios, y el indirecto del sufragio activo. Todo esto acaso habría conferido a las Cortes y al sistema político un sesgo acusadamente burgués, en consonancia con las ideas imperantes en la época y con el régimen económico y de libertades públicas perfilado por las Cortes gaditanas. Así, pues, se dispusieron todas las piezas para que la Cámara fuese burguesa, tanto por los elegidos, dados los requisitos que se les exigían, como por los electores finales (los provinciales), sucesivamente filtrados a través de las mencionadas cuatro fases, a cuyo término habrían terminado prevaleciendo las personas más preparadas y pudientes.

No obstante lo cual, como indica el citado autor, las Cortes de Cádiz tuvieron una representatividad muy superior a la de los países que las habían precedido en la vía revolucionaria.

\section{PODER CONSTITUYENTE POPULAR}

\subsection{Soberanía y poder constituyente}

El principio de soberanía nacional/popular comporta igualmente el de la titularidad nacional/popular del poder constituyente. Aunque, como anota TOMÁS Y VALIENTE, Argüelles oculta sus fuentes y no utiliza los conceptos de SIEYÈS, para él, como para éste, «la suprema manifestación de la soberanía es el poder constituyente» ${ }^{101}$. También le corresponde el poder constituyente constituido, esto es, el poder de reforma constitucional. Y, si bien yo estimo que el instituto del mandato representativo, tal como fue integrado en el constitucionalismo de primer cuño y ha quedado en el demoliberal, no es

100 ARTOLA, M.: Antiguo Régimen y revolución liberal, ob. cit., págs. 166-167.

101 TOMÁS Y VALIENTE, F.: «Agustín de Argüelles en Cádiz», ob. cit., pág. 4595. 
una consecuencia necesaria de la soberanía nacional, es cierto que, al menos históricamente, se han dado unidos. A ambos me refiero sumariamente a continuación.

Los caracteres del poder constituyente se infieren de su concepto y del concepto de soberanía popular:

a) Es un poder radical; esto es: su titularidad hunde su raíz en el propio pueblo sin instancia intermedia alguna.

b) Es extraordinario: actúa sólo en momentos fundacionales o de cambio político de cierta entidad.

c) Es permanente, aunque, por lo dicho anteriormente, de ejercicio discontinuo.

d) Es unitario e indivisible, en el sentido y en la medida en que lo es su titular, bien que integrado por millones de individuos.

e) Es inalienable, como lo es la soberanía y todo elemento del Estado.

f) Su ejercicio no tiene más condición que la democracia, tanto en el procedimiento seguido como en el resultado final.

En efecto, la proyección fundamental de la soberanía es justamente la confección de una Constitución. Su titular, por tanto, es y sólo puede ser el pueblo y su ejercicio es acometido por éste actuando ora directamente, ora por medio de sus representantes, como ha venido siendo lo habitual, ora, en fin, de una manera combinada. Por eso, como trasunto directo de la soberanía, cuanta mayor y más directa sea la intervención del pueblo en tal ejercicio, tanta mayor frescura democrática alcanza a la Constitución y al régimen que instaura. Cualquier observador sabe diferenciar grados y matices entre una Constitución aprobada exclusivamente por un Parlamento ordinario y otra en la que el pueblo ha intervenido doblemente: una vez para elegir un Parlamento Constituyente, y otra para aprobar la Constitución mediante referendo, sin perjuicio de que el producto sea en ambos supuestos democrático.

Pero además el procedimiento constituyente ha de ser respetuoso con las minorías y con los principios básicos de los debates políticos en regímenes democráticos. En segundo término, el resultado ha de ser una Constitución que instaure, sostenga o refuerce la democracia; o, dicho más rotundamente, su objeto ha de ser una Constitución que lo sea realmente y no un disfraz de la autocracia. En este último caso, puede haber un acto de soberanía, pero no del poder constituyente porque no tiene por objeto una Constitución.

De lo dicho se desprenden dos conceptos de poder constituyente. Según un concepto amplio y neutro, es el poder de decisión sobre la Constitución; dicho con palabras de C. SCHMITT, es «la voluntad política cuya fuerza o autoridad es capaz de adoptar la concreta decisión de conjunto sobre modo y forma de la pro- 
pia existencia política» (cursiva del original) ${ }^{102}$, lo cual no es sino llamar de otra manera al mismo principio. Según un concepto más estricto, en línea con lo explicado hasta aquí, únicamente lo es el democrático, pues sólo éste puede realmente limitar el poder y garantizar la libertad ${ }^{103}$.

Asentado lo anterior, podemos definir el poder constituyente en sentido estricto como la voluntad política del pueblo que decide sobre su propia existencia democrática. De donde se deduce lógicamente, como una exigencia del concepto de democracia, el repudio de todo acto, por libre y participativo que sea, cuyo objeto y resultado consista en la liquidación de la democracia.

Requisito inexcusable para una correcta intelección de este instituto es la previa diferenciación entre poder constituyente y poderes constituidos:

a) El poder constituyente propiamente dicho (conocido como originario) corresponde esencialmente a la nación y suele ser ejercido por una Convención o Asamblea surgida de un proceso revolucionario.

b) Los poderes constituidos corresponden a los órganos estatales a los que la Constitución se los atribuye.

c) A su vez, entre los poderes constituidos se pone de relieve una diferencia crucial, sustantiva: la existente entre los poderes ordinarios clásicos (y, en nuestros días por otros que la experiencia constitucional ha ido añadiendo a la maquinaria estatal), que son de funcionamiento diario, y el poder extraordinario de revisión constitucional.

El poder constituyente originario es previo a la Constitución, él hace la Constitución. El poder de revisión es constituido, como los ordinarios, porque es obra de la Constitución, la cual lo regula y somete a procedimiento. Pero es extraordinario por su función y por su ejercicio ocasional o intermitente, además de que suele serlo por su procedimiento. Por eso se dice de él que ocupa una posición intermedia entre el poder constituyente originario y el poder legislativo, ya que, al igual que el poder legislativo, deriva de la Constitución y está regulado por ella, pero a diferencia de éste y a semejanza del primero, puede modificar la Constitución, incluso en su totalidad. Se lo conoce como poder constituyente

102 SCHMITT, C.: Teoría de la Constitución, edic. cast. Editorial Revista de Derecho Privado, Madrid, s. f., pág. 86.

${ }^{103}$ Los resultados, en cambio, no siempre se corresponden con la bondad del procedimiento, y así, ni una Constitución elaborada con mucha participación ciudadana es necesariamente de mejor calidad técnico-jurídica que otra hecha por un Parlamento ordinario que asume dicha función, ni aquélla tiene asegurada una vigencia pacífica y duradera en tanto que la segunda habrá necesariamente de tener una vida convulsa y efímera. Las cosas no son tan simples y menos en cuestiones jurídico-políticas. 
constituido, poder constituyente derivado o simplemente poder de reforma o de revisión constitucional.

\subsection{Textos iniciales del constitucionalismo}

Ciertamente cabe buscar antecedentes de un embrionario concepto de poder constituyente en el Agreement of the people, documento también revolucionario redactado en plena experiencia republicana inglesa; era considerado como un pacto política y jurídicamente superior al propio Parlamento. Y los colonos americanos plasmaron una idea similar, no del todo nítida, en la Declaración de Independencia (1776) y en las Declaraciones de Derechos y Constituciones de los flamantes Estados, como los de Connecticut, Massachusetts y New Hampshire, así como en la Constitución federal de 1787.

No hay textos relativos al poder constituyente en la Enciclopedia. Ni siquiera tuvo entrada en ella la voz «Constitución». Pero en plena revolución fue crucial el tratamiento que de él hizo SIEYÈS (su obra más conocida, ¿Qué es el tercer estado?, data de 1789). Y, aunque el oportunismo político le dictó alguna contradicción, podemos resumir aquí algunas de sus ideas menos coyunturales relativas al problema que estamos tratando en este subepígrafe, las cuales conforman, desde luego, la primera teoría sólida sobre esta materia. Algo de ello hemos avanzado en los párrafos anteriores:

a) La nación, constituida por el tercer estado, esto es por los ciudadanos no privilegiados, es soberana y, como tal, es titular del poder constituyente, que es derivación de la soberanía y consiste en la facultad de dotarse de la forma política que quiera y de cambiarla sin límite alguno.

b) Este poder constituyente es distinto de los clásicos poderes montesquiniamos (legislativo, ejecutivo y judicial, como también del poder federativo lockeano). La diferencia reside en que aquél es un poder que radica en la nación, en virtud del cual se dota de una Constitución, mientras que los otros poderes son resultado de éste y están regulados en ella.

c) Pero, como la nación no puede reunirse, es preciso que confíe los asuntos políticos a representantes. La nación no puede querer (vale decir actuar, expresar su voluntad) sino a través de sus representantes, los cuales son ordinarios si son elegidos para una Asamblea Nacional común, cuya función principal es legislar, y extraordinarios si lo son para hacer una Constitución. Éstos últimos son elegidos expresa y exclusivamente para dicho fin, debiendo abstenerse de ejercer otros poderes distintos.

El título VII de la Constitución de 1791, que es el que regula la reforma constitucional, atribuye a la Nación, que actúa por medio de sus representantes, 
el derecho imprescriptible de cambiar $s u$ Constitución, a través de un procedimiento que alcanzaría a seis legislaturas, aunque sólo $\left.{ }_{i}\right)$ intervendrían cuatro porque la cuarta y la quinta no podían hacer ninguna propuesta al efecto. La última y decisiva tendría una composición aumentada, pero ese contingente de diputados añadidos se retiraría una vez ultimada la reforma sin poder participar en la función legislativa ordinaria.

Por su parte, la Constitución girondina reconoce el derecho de reforma constitucional al pueblo (art. 33 del Proyecto de Declaración de Derechos) y no al Cuerpo legislativo, el cual, por disposición del Proyecto de Acta Constitucional, artículos 158-159, tenía precisamente en sus funciones el límite constitucional. Por eso la iniciativa de reforma es popular, y la parlamentaria requería la aprobación de la mayoría del pueblo francés (arts. 250-265). El Cuerpo Legislativo convocaría una Convención nacional, cuya función sería la de presentar un proyecto de Constitución pulida de errores y defectos y perfeccionada, en cuya función no podría excederse de un año. La aprobación correspondía al pueblo en la forma que determinara la Constitución vigente en ese momento.

Igualmente, la Constitución jacobina, en su Declaración de Derechos, artículo 28, reconoce al pueblo el derecho de revisar, reformar y cambiar $s u$ Constitución, añadiendo en tono impropiamente doctrinal: «Una generación no puede sujetar con sus leyes a las generaciones futuras». Y los artículos 115 a 117 del Acta Constitucional atribuían la función de reforma a la Convención que se convocara al efecto, la cual tendría el poder de reforma limitado a lo especificado en la convocatoria, pero asumiría también los poderes de la legislatura ordinaria.

En fin, el texto de 1795 (título XIII, arts. 336-350) confería la iniciativa al Consejo de los Ancianos y necesitaba la ratificación del Consejo de los Quinientos y su confirmación en tres momentos diferentes separados entre sí por no menos de tres años; sólo entonces se convocaría una Asamblea de Revisión con la única función de proceder a la reforma en un tiempo tasado de tres meses; una vez ultimada ésta, se remitiría para su aprobación a las Asambleas primarias.

En cuanto a la Constitución federal de Estados Unidos, todo el procedimiento de reforma o de enmienda constitucional se desarrolla en sedes institucionales, según establece el artículo $5^{\circ}$. La iniciativa corresponde al Congreso o a petición de las legislaturas de dos terceras partes de los Estados miembros, y requiere la ratificación, según disponga el Congreso, de las legislaturas de tres cuartas partes de éstos o de convenciones celebradas en la misma cantidad de Estados. 


\subsection{Constitución gaditana}

\subsubsection{Titularidad del poder constituyente y poder de reforma constitucional}

En consonancia con lo anticipado en las últimas páginas y como expusimos en su momento, el diputado conde de Toreno decía en sede constituyente que a la nación, como soberana, es a la única que le corresponde el derecho de establecer sus leyes fundamentales y de determinar su forma de gobierno. Este principio fue recogido por el Proyecto de Constitución y por el Discurso Preliminar. Finalmente, el texto constitucional, en su artículo $3^{\circ}$, suprimió la alusión a la forma de gobierno y lo dejó en el establecimiento de sus leyes fundamentales, suficientemente expresivo del concepto de poder constituyente:

«La soberanía reside esencialmente en la Nación, y por lo mismo pertenece a ésta exclusivamente el derecho de establecer sus leyes fundamentales».

Sin entrar a comentar la impropia fórmula argumentada de la segunda frase del precepto ("y por lo mismo") sí anotaré que, en función de esa esencialidad de la soberanía nacional y de la condición representativa que las Cortes ostentaban de esa soberanía, éstas decretaron y sancionaron la Constitución. Nos centramos, pues, en el reconocimiento de la nación como titular exclusiva ${ }^{104}$, también, del poder de reforma constitucional.

Y este poder de reforma plantea, de entrada, un escollo. Reparemos en que los diputados, en el ejercicio de sus funciones ordinarias, tenían como límite material la propia Constitución, sin que pudieran derogar, alterar o variar sus preceptos en manera alguna ni bajo ningún pretexto. Pero la Constitución prevé su propia reforma. Lo hace en su título X y último (arts. 372 a 384), si bien se declaraba temporalmente pétrea. La aparente contradicción se salva por la consideración de esta otra función como extraordinaria, del mismo modo que extraordinario, por diferente y costoso, era el procedimiento a seguir, en el que, una vez más, la Nación quiere y decide a través de sus representantes.

Atendiendo a esta potestad de las Cortes y para salvar el escollo mentado, el artículo 382 ordenaba que los diputados electos de la última legislatura que intervenía en la reforma, que eran los que habrían de ultimar el texto definitivo, recibieran de las Juntas electorales provinciales, junto a los poderes ordinarios que

104 Como advierte sin necesidad TOMÁS Y VALIENTE, el adverbio «exclusivamente» no significa que la nación sólo tenga ese derecho, sino que ese derecho pertenece sólo a ella («Agustín de Argüelles en Cádiz», ob. cit., pág. 4594). 
ya conocemos, un mandato extraordinario ad hoc, de reforma constitucional, que rezaba de la siguiente guisa:

«Asimismo les otorgan poder especial para hacer en la Constitución la reforma de que trata el decreto de las Cortes [el que contenía la propuesta], cuyo tenor es el siguiente (aquí el decreto literal). Todo con arreglo a lo prevenido en la propia Constitución. Y se obligan a reconocer y tener por constitucional lo que en su virtud establecieren».

Podemos ver en ello una última reminiscencia del mandato imperativo, ya que no podían extralimitarse de la reforma que venía propuesta en el referido decreto.

Junto a esta peculiaridad del texto de 1812, el constituyente bebió de fuentes foráneas en todos o en casi todos los demás aspectos del procedimiento de reforma, como era de esperar, principalmente de los textos de 1791 a 1795. También son detectables algunas similitudes con la Constitución federal de Estados Unidos de 1787. Entre los múltiples parentescos que guarda nuestra primera Constitución con una o varias de las referidas, señalaremos, como mera muestra, las siguientes:

1. La Constitución gaditana cumple con el modelo teórico, distinguiendo, de una parte, el poder constituyente y los poderes constituidos; y, de otra, entre éstos, el poder constituyente constituido, o poder de reforma, y los poderes ordinarios. $\mathrm{Y}$ así es factible identificar en su texto tres Cortes distintas: además de las Constituyentes que le dieron vida (y que habrían de desaparecer con la entrada en vigor del texto alumbrado, aunque, por razones que no nos corresponde analizar ahora, prolongaron algo su existencia), las Cortes de reforma constitucional y las ordinarias. Incluso, por lo que se refiere a sus respectivos procedimientos de actuación, las diferencia de manera excesivamente abultada.

2. La Constitución de Estados Unidos marcó una pauta importante que después han seguido muchas otras que son producto de una revolución: la intangibilidad temporal del texto; en Estados Unidos, fue una intangibilidad meramente parcial, pero en el constitucionalismo francés y en el gaditano fue total.

3. Las Constituciones de 1791 a 1795 confirieron la potestad de reforma a Asambleas unicamerales, como después hizo la Constitución española de 1812; con algunas diferencias, a saber: las Asambleas francesas, salvo la del texto de 1791, eran extraordinarias y convocadas al efecto, en tanto que el constituyente gaditano se inclinó por unas Cortes iguales que las ordinarias, pero investidas de un poder (mandato) especial, según hemos visto. 
4. Nuestra primera Constitución coincide con la de 1791 y discrepa de las demás en que la Cámara reformadora tenía además poderes legislativos ordinarios.

5. Vuelve el constituyente español a tomar del francés de 1791 y del jacobino la intervención de varias legislaturas en el procedimiento de reforma, con diferencias, ciertamente, pero con esa coincidencia sustancial.

6. Como hay también coincidencia en silenciar los límites materiales al poder de reforma en general junto con el estricto atenimiento de éste, una vez iniciado el procedimiento, a la materia reformable que figurara en la propuesta o en el poder (mandato) recibido respectivamente.

7. Y, en fin, la española vuelve a tomar de las francesas la exclusión total del Rey en todas las fases del procedimiento, incluidas la sanción y promulgación. Los textos franceses republicanos guardan un silencio que debe ser interpretado como negativo; y el de 1791 dispone que sea la Asamblea Nacional la que apruebe el Acta Constitucional y ese mismo día nombre una Comisión para presentársela al Rey ${ }^{105}$, lo que significa igualmente ausencia de sanción y promulgación.

\subsubsection{Constitución y ley}

Pero, por otra parte, salvo el muy débil mecanismo de las denuncias por infracción de la Constitución, el constituyente no incluyó en su obra más mecanismo de defensa de ésta que su excesiva rigidez, en cuya exposición no entraré en el presente trabajo ${ }^{106}$. ¿Por qué estableció un procedimiento de reforma tan extremadamente complejo y lento? ¿Hacia quién se dirigían sus recelos o suspicacias?

Recordemos, en primer lugar, que la hiperrigidez e incluso la intangibilidad son propias de Constituciones revolucionarias o que significan un gran cambio político en el país. El constituyente, celoso de su obra, la protege incluso más allá de lo prudente. Hay en ello obviamente una desconfianza en los poderes ordinarios que han de gobernar aplicando la Constitución. ¿De cuáles desconfiaba el constituyente gaditano?

105 Estimo que ésta es la traducción adecuada del precepto, que dice «pour offrir... au Roi» (art. $8^{\circ}$. pfo. $6^{\circ}$ del título VII).

106 Remito a sendos trabajos de J. TAJADURA TEJADA y J. M. VERA SANTOS, insertos en el próximo número de esta Revista. 
No olvidemos que, como apunta J. VARELA, la de 1812 era una Constitución innovadora y subversiva del orden político anterior y sus mentores principales, los liberales, temían que se cernieran sobre ella muchas amenazas (como puede leerse en el Diario de Sesiones y en el mismo Discurso Preliminar), provenientes de las fuerzas sociales perjudicadas, del mismo pueblo, ajeno a tales ideas, y de las burguesías criollas. De ahí que los diputados realistas y los «americanos» se opusieran a la rigidez del texto. La mayoría liberal, sin embargo, impuso la intangibilidad temporal y la rigidez, con las que buscaba evitar una reforma prematura que impidiese la consolidación del nuevo orden, e impedir que lo hiciese una débil mayoría parlamentaria o incluso el propio monarca ${ }^{107}$.

Más allá de las fuerzas sociales y políticas contrarias a la Constitución y a su rigidez, y atendiendo a las instituciones de las que recelaba el constituyente gaditano, parece, prima facie, que fuera el Rey el blanco de su desconfianza y temores, más que justificados por cierto y exteriorizados en la débil participación regia en el poder legislativo y en las muchas «restricciones» de su autoridad insertas en el artículo 172. Pero también debió pesar en el ánimo del constituyente un cierto recelo respecto de las futuras Cortes ordinarias, que podrían aprovechar su posición preeminente en la potestad legislativa para aprobar algunas leyes que fueran reformas subrepticias de la Constitución.

Abona esta conjetura la lectura de los poderes que las Juntas Electorales Provinciales otorgaban a los diputados electos para dichas Cortes ordinarias, los cuales eran ciertamente muy amplios y revestían a los diputados de autoridad y legitimidad en cuanto hicieren, pero con el límite expreso de la materia constitucional. Así rezaban:

«(...) les otorgan poderes... para que... puedan acordar y resolver cuanto entendieren conducente al bien general de ella 〔la Nación ] en uso de las facultades que la Constitución determina, y dentro de los límites que la misma prescribe, sin poder derogar, alterar o variar en manera alguna ninguno de sus artículos bajo ningún pretexto» (art. 100).

El texto es suficientemente expresivo, y hasta enérgico, de los límites de su poder. Y, aunque puede parecer mera anécdota, se inscribe en esa misma finalidad la propia continuación en ejercicio de las Cortes Constituyentes durante un año una vez promulgada la Constitución, cuando su destino natural era la autodisolución para dejar paso a unas Cortes ordinarias.

Pero, como hemos dicho, esos recelos hacia unas Cortes ordinarias que pudieran malograr «su Constitución» no se tradujeron en dispositivos de ga-

107 VARELA SUANCES-CARPEGNA, J.: La Teoría del Estado..., ob. cit., págs. 399-421. 
rantía de la supremacía normativa de la Constitución, habiendo como había ya un precedente en Estados Unidos. Ello obedeció a que el constituyente siguió en esta cuestión el planteamiento rusoniano, consagrado en las Constituciones revolucionarias francesas: el Parlamento es representante de la soberanía nacional, de la voluntad general; la expresaban tanto como la Constitución, por lo que no había lugar a la declaración de inconstitucionalidad de su principal producto: la ley ${ }^{108}$. Además, una de las facultades que la Constitución atribuye a las Cortes era la de la interpretación de las leyes y, como consecuencia, en caso de discrepancia entre la Ley y la Constitución, eran las propias Cortes las que tendrían que salvar el escollo mediante el ejercicio de esta facultad ${ }^{109}$. No obstante lo cual, o precisamente por eso, el constituyente creyó oportuno tomar precauciones respecto de las futuras Cortes ordinarias en forma de hiperrigidez del texto constitucional, disponiendo un muy complejo procedimiento para su reforma.

La complejidad de la reforma constitucional gaditana rayaba en la intangibilidad, idea que se refuerza precisamente con la intangibilidad temporal de la Constitución, la cual no podía modificarse hasta pasados ocho años de haber sido puesta en práctica en todas sus partes (art. 375). Se comprenderá entonces que nunca fuera reformada por más que se sintiera su necesidad o conveniencia.

(Por cierto que, como mera anécdota, el propio constituyente previó, o más bien ordenó, una reforma concreta, la de la división territorial de España «luego que las circunstancias políticas de la nación lo permitan» (art. 11). Parece plausible la interpretación de I. FERNÁNDEZ SARASOLA de la inaplicabilidad en este caso de la intangibilidad temporal ${ }^{110}$. La única condición que impone el recepto es la de abordar dicha reforma «luego que las circunstancias políticas de la Nación lo permitan», condición que bien se podía estimar cumplida una vez acabada la guerra. Estaríamos, por tanto, ante una norma especial que desplaza la aplicación de la norma general de intangibilidad temporal.)

De hecho, ni siquiera se hizo la reforma en un momento tan propicio como el trienio constitucional, en el que se, además de tomar nota de los nuevos aires constitucionales de Europa, se hubieran podido extraer las conclusiones adecuadas de la

108 Tesis que tiene cierto paralelo, pese a que provienen de distintas fuentes y han seguido diferente desarrollo institucional, con el dogma principal del constitucionalismo británico durante varios siglos: la soberanía del Parlamento, que se extendió al constitucionalismo europeo como soberanía de la ley.

109 Cfr. FERNÁNDEZ SARASOLA, I.: La Constitución de Cádiz. Origen, contenido y proyección internacional, Centro de Estudios Políticos y Constitucionales, Madrid, 2011, págs. 126-129.

110 Ibidem, pág. 220. 
experiencia anterior, para así acondicionar el texto constitucional a las necesidades reales del país. Y cuando más adelante, tras el motín de La Granja y otros episodios convergentes, el Partido Progresista, que propugnaba una nueva vigencia de la Constitución gaditana para proceder a su reforma, fue llamado por la Regente para formar Gobierno, ésta se hizo siguiendo un iter diferente del establecido ${ }^{111}$. La hiperrigidez de la Constitución terminó siendo una invitación a transgredirla.

\section{CONCLUSIÓN Y REMISIÓN: UNA INCIPIENTE DEMOCRACIA REPRESENTATIVA}

A. FERNÁNDEZ DOMÍNGUEZ ha destacado oportunamente que la Instrucción electoral de $1^{\circ}$ de enero de 1810 «constituye el establecimiento del primer régimen electoral de la historia contemporánea española; y, además, significa el tránsito de la representación estamental o del Antiguo Régimen a la representación nacional y burguesa» ${ }^{112}$ que ostentaban las Cortes.

Las funciones de las Cortes diseñadas por la Constitución, que eran propiamente legislativas y de control y no meramente consultivas como las de las históricas Cortes de Castilla, y su naturaleza de representación nacional y no corporativa ni estamental, como fue la vigente en el Antiguo Régimen, hizo de las Cortes de Cádiz, tanto — anticipadamente- de las constituyentes como de las ordinarias reguladas en la Constitución, el primer y segundo Parlamentos españoles propiamente dichos.

De ahí los infructuosos esfuerzos de MARTÍNEZ MARINA por demostrar que desde el Medievo había en España unas Cortes al modo de Parlamento, por lo que las Cortes de Cádiz no contradecían la tradición nacional, tesis, muy desacreditada a juicio de J. A. ESCUDERO ${ }^{113}$. En el mismo sentido ha subrayado A. TUÑÓN DE LARA que las Cortes de Cádiz fueron el primer Parlamento español en el sentido moderno de la palabra y en ellas se perfilaron los embriones de los futuros partidos políticos.

111 Irregularidad que casi se hizo» normal» en nuestro país, pues volvería a producirse en 1869 y 1876. Cfr. TOMÁS VILLARROYA, J.: «La Constitución de 1812 en la época del Estatuto Real», Revista de Estudios Políticos, n 126, Madrid, 1962, págs. 251 ss.

112 FERNÁNDEZ DOMÍNGUEZ, A.: «La Constitución española de 1812. Régimen electoral y elecciones de diputados a Cortes ordinarias de 1813»; en CANO BUESO, J. (ed.): Materiales para el estudio de la Constitución de 1812, Parlamento de Andalucía, Sevilla, 1992, pág. 253.

113 ESCUDERO, J. A.: «Estudio introductorio» a MARTÍNEZ MARINA, F.: Teoría de las Cortes, Clásicos Asturianos del Pensamiento Político, Oviedo, 1996, págs. CLVI-CLVII. 
En conclusión, el principio de soberanía nacional y su elemento fundamental, el poder constituyente popular, los cuales, a su vez, se instrumentaban mediante el sufragio universal (con los matices que hemos apuntado); la instauración de un verdadero Parlamento (autónomo y titular de la potestad legislativa); el paso decidido, aunque no completo, hacia el mandato representativo, y la inexistencia de instituciones de participación popular directa hacen que fuera un Estado representativo el perfilado en la Constitución de 1812. Integrados — que no yuxtapuestos- estos elementos, el régimen resultante era, (o debería haber sido, puesto que quedó en suspenso) una incipiente democracia representativa.

Lo veremos más ampliamente en un trabajo dedicado a las Cortes que se incluye en el próximo número de esta Revista ${ }^{114}$.

114 TUÑÓN DE LARA, A.: La España del siglo XIX, Laia, Barcelona, 1974, pág. 24. 
Title:

NATIONAL SOVEREIGNTY IN THE CONSTITUTION OF CADIZ

\section{Summary:}

1. Introduction: The long march of sovereignty from feudal pluralism to the Enlightenment: 1.1. The sovereignty of divine origin. 1.2. Towards terrenalización of sovereignty. 2.- National sovereignty versus popular sovereignty: 2.1. The topical distinctive theory. 2.2. His failure 2.2.1. Approach to the problem. 2.2.2. Doctrinal and legal texts: 2.2.2.1. French texts. 2.2.2.2. American texts. 3.- The public as a key concept: 3.1. Doctrinal and legal texts 3.1.1. French texts. 3.1.2. American texts. 4.- National sovereignty / popular in the Spanish Constitution of 1812: 4.1 Pre-historical look at the Spanish constitutionalism. 4.2. In particular, the Constitution of 1812: 4.2.1. Sovereignty. 4.2.2. The nation as a state. 5.- Citizenship in Cádiz: 5.1. The right of citizenship. 5.2. Spanish and citizens. 5.3. The status of citizen, legally open. 5.4. Any comparison to avoid anachronisms. 5.5. Conclusion: the controversial vote «Cadiz». 6.- Popular constituent power: 6.1. Sovereignty and constituent power. 6.2. Original texts of constitutionalism. 6.3. Cadiz Constitution: 6.3.1. Ownership of the constituent power and power of constitutional reform. 6.3.2. Constitution and law. 7.- Conclusion and referral: A fledgling representative democracy

\section{Resumen:}

En este trabajo se hace un cotejo entre el principio de soberanía nacional, propio del constitucionalismo (no de las llamadas «Constituciones»o «Leyes Fundamentales» del Antiguo Régimen) y la primera Constitución española, de1812. Para ello, en primer lugar, se descarta por insuficiente la teoría que diferencia la soberanía nacional y la soberanía popular; después se cifra la diferencia entre las Constituciones más o menos democráticas en el concepto de ciudadanía, del que se solía escindir el de ciudadanía activa. Se estudia más adelante el poder constituyente como derivado de la soberanía, el carácter más o menos universal del sufragio y un modelo de representación más próximo al mandato representativo que al imperativo. De este análisis se concluye que la Constitución gaditana incorporó, en dosis variadas, todos estos elementos del constitucionalismo y se ponen de relieve los textos más significativos al respecto. 


\begin{abstract}
:
This paper makes a comparison between the principle of national sovereignty, constitutionalism itself (not the so-called «constitution» or «fundamental laws» of the Old Regime) and the first Spanish Constitution, de1812. To do this, first, it is discarded as inadequate theory differentiates national sovereignty and popular sovereignty, then figure the difference between more or less democratic constitutions in the concept of citizenship, which is used to split the active citizenship. Discussed below constituent power as a byproduct of sovereignty, the more or less universal suffrage and representation model representative office closest to that imperative. This analysis concludes that the Constitution of Cadiz joined, in varying doses, all these elements of constitutionalism and highlights the most significant texts about.
\end{abstract}

\title{
Palabras clave:
}

Nación, pueblo, soberanía, soberanía nacional, soberanía popular, poder constituyente, poder de reforma constitucional, ciudadanía, sufragio universal, mandato representativo, democracia representativa

\section{Key words:}

Nation, people, sovereignty, national sovereignty, popular sovereignty, constituent power, the power of constitutional reform, citizenship, universal suffrage, representative office, representative democracy. 
